\title{
DISTRIBUTION, CONDITION, AND GROWTH OF NEWLY SETTLED SOUTHERN FLOUNDER (Paralichthys lethostigma) IN THE GALVESTON BAY ESTUARY, TX
}

\author{
A Thesis \\ by \\ LINDSAY ANN GLASS \\ Submitted to the Office of Graduate Studies of \\ Texas A\&M University \\ in partial fulfillment of the requirements for the degree of \\ MASTER OF SCIENCE
}

May 2006

Major Subject: Wildlife and Fisheries Sciences 


\title{
DISTRIBUTION, CONDITION, AND GROWTH OF NEWLY \\ SETTLED SOUTHERN FLOUNDER (Paralichthys lethostigma) IN \\ THE GALVESTON BAY ESTUARY, TX
}

\author{
A Thesis \\ by \\ LINDSAY ANN GLASS \\ Submitted to the Office of Graduate Studies of \\ Texas A\&M University \\ in partial fulfillment of the requirements for the degree of \\ MASTER OF SCIENCE
}

Approved by:

Chair of Committee, Jay R. Rooker

Committee Members, William H. Neill

Antonietta Quigg

Head of Department, Delbert M.Gatlin III

May 2006

Major Subject: Wildlife and Fisheries Sciences 


\begin{abstract}
Distribution, Condition, and Growth of Newly Settled Southern Flounder (Paralichthys lethostigma) in the Galveston Bay Estuary, TX. (May 2006) Lindsay Ann Glass, B.S., Texas A\&M University-Galveston Chair of Advisory Committee: Dr. Jay R. Rooker
\end{abstract}

Several flatfish species including southern flounder (Paralichthys lethostigma) recruit to estuaries during early life. Therefore, the evaluation of estuarine sites and habitats that serve as nurseries is critical to conservation and management efforts. I used biochemical condition and growth measurements in conjunction with catch-density data to evaluate settlement sites used by southern flounder in the Galveston Bay Estuary (GBE). In 2005, beam-trawl collections were made in three major sections of the GBE (East Bay, West Bay, Galveston Bay), and three sites were sampled in each bay. Within each sampling site, replicate collections were taken from 1) the marsh edge, 2) an intermediate zone, and 3) the open bay. The average size of southern flounder collected was between 12 and $19 \mathrm{~mm}$ standard length, and peak densities occurred in January and February. Catch data indicated that numeric densities of southern flounder were significantly greater in East Bay $\left(2.75\right.$ per $\left.100 \mathrm{~m}^{2}\right)$ than in West Bay $\left(0.45\right.$ per $\left.100 \mathrm{~m}^{2}\right)$ or in Galveston Bay $\left(0.91\right.$ per $\left.100 \mathrm{~m}^{2}\right)$. Habitat-specific variation in density was not found. Otolith-based estimates of age indicated that the majority of southern flounder collected were 35-45 days old and derived from early December to early January hatch-dates. Growth rate differences were negligible across bays and habitats, with the average growth rate being $0.40 \mathrm{~mm} /$ day (range $0.21-0.76 \mathrm{~mm} /$ day). RNA:DNA ratios indicated that newly settled southern flounder in the GBE were in relatively high condition. 
Habitat-specific differences in RNA:DNA ratios were not observed; however, ratios were significantly lower in West Bay (average 8.0) than in East Bay (average 9.5) or in Galveston Bay (average 9.8), suggesting the condition of new recruits may vary across the GBE. Findings from this study indicate that southern flounder use a variety of habitats within the GBE during early life, and survival and recruitment success appear favorable regardless of settlement site. As a result, recruitment success of southern flounder may be less a function of the quality of nursery sites/habitats within the GBE than of other factors (e.g., larval supply to the estuary). 


\section{ACKNOWLEDGEMENTS}

I thank my advisor Dr. Jay Rooker for guidance and support throughout my work. Thanks, Jay, for all the advice, manuscript shaping and editing, and mentoring that have made my Master's degree a valuable learning experience. I also thank Drs. William H. Neill and Antonietta Quigg for serving on my committee and for their reviews and advice on my thesis.

I express sincere gratitude to Dr. Richard Kraus, who kept me going when I wanted to quit. Richard, thanks for challenging me intellectually and pressing me to be a better scientist.

I would like thank all those in the Fisheries Ecology Lab: Jessica Beck, Joe Mikulas, and Yan Cai. Special thanks to Bert Geary and Michelle Zapp for field help, especially on the cold and rainy days, and to the many others who volunteered their time to help me in the field. 


\section{TABLE OF CONTENTS}

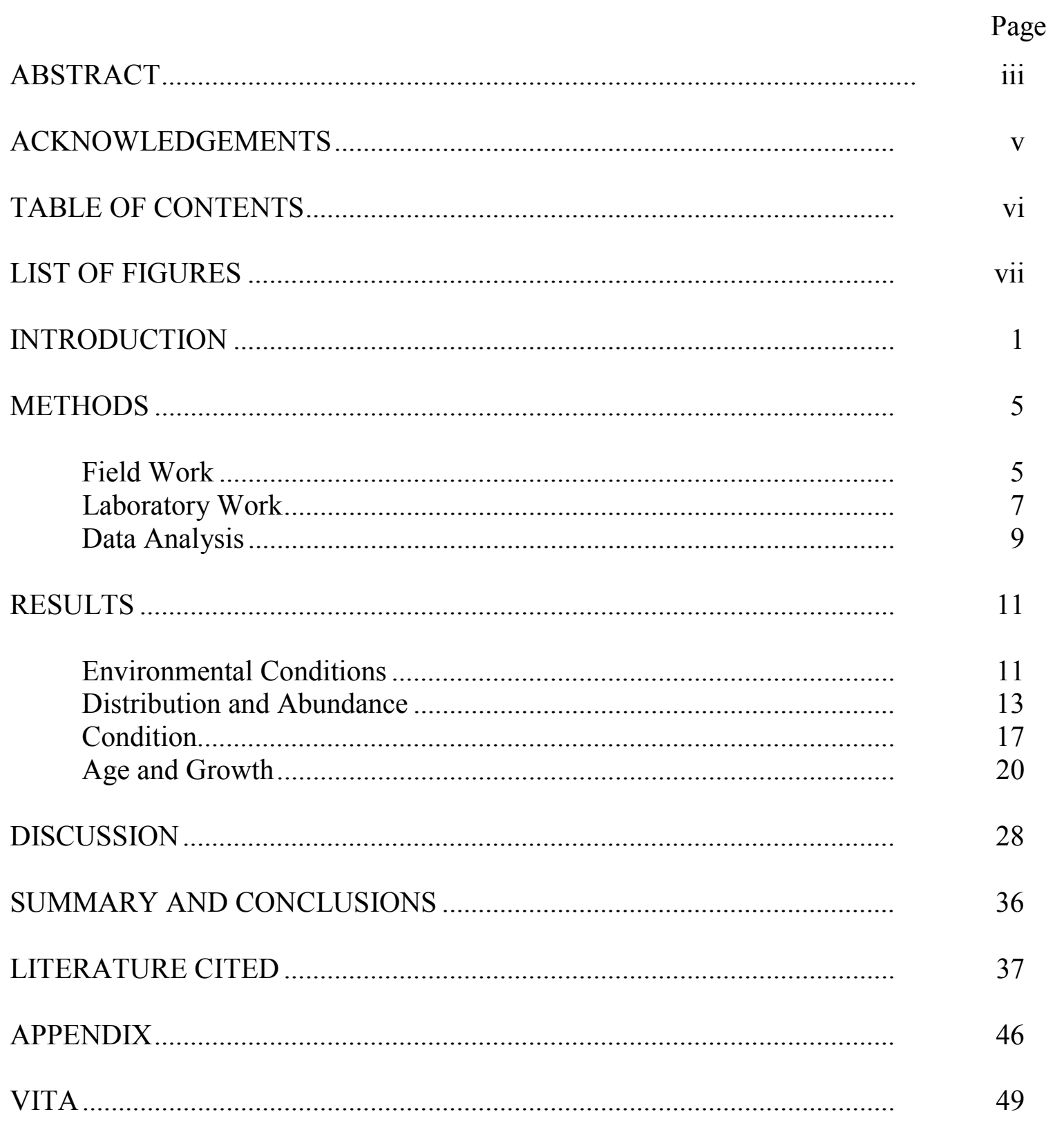




\section{LIST OF FIGURES}

FIGURE Page

1 Map of study area and sampling sites in the Galveston Bay Estuary................ 6

2 Seasonal variation in the number of larval or juvenile flatfishes (bay whiff, blackcheek tonguefish, fringed flounder, and southern flounder) from the Galveston Bay Estuary in 2005

3 Length-frequency distributions of newly settled southern flounder from the Galveston Bay Estuary in 2005.

4 Densities (number per $100 \mathrm{~m}^{2}$ ) of newly settled southern flounder collected from the Galveston Bay Estuary in 2005.

5 RNA:DNA ratios of newly settled southern flounder from the Galveston Bay Estuary in 2005.

6 Mean RNA:DNA ratios for newly settled southern flounder from the Galveston Bay Estuary in 2005

7 Age-frequency distribution of newly settled southern flounder from the Galveston Bay Estuary in 2005.

8 Hatch-date distribution of newly settled southern flounder from the Galveston Bay Estuary in 2005.

9 Size-at-age relationship for newly settled southern flounder from the Galveston Bay Estuary (all sites pooled) in $2005(\mathrm{n}=100)$.

10 Mean growth rates $(\mathrm{mm} /$ day) of newly settled southern flounder from the Galveston Bay Estuary in 2005.

11 Growth rates for newly settled southern flounder collected from the Galveston Bay Estuary in 2005 separated into hatch-date cohorts (December and January).

12 Recent growth of newly settled southern flounder from the Galveston Bay Estuary in 2005. 


\section{INTRODUCTION}

Effectively managing estuarine nursery habitats requires an understanding of population dynamics and the causes of variability in recruitment (Houde 1987; Sinclair 1988; Jones 1990; Cushing and Horwood 1994; Leggett and DeBlois 1994; Rooker and Holt 1996). Recruitment of fishes can vary both temporally (several influxes of recruits in a season) and spatially (recruitment to different areas), and recruitment areas can be disjoined from spawning areas (Cowan and Shaw 2002). Usually a spawning ground is fixed, and environmental variation in factors associated with hydrography dictates the number of larvae that are transported to the nursery (Sinclair 1988). Hjort (1914) suggested that food was a limiting factor during the first-feeding stage or "critical period" of larvae, and starvation-induced mortality during this period was an important determinant of recruitment variability. Cushing (1996) expanded Hjort's "critical period" hypothesis and suggested that food-mediated mortality during any part of the larval period would affect larval abundance and recruitment success. Although evidence demonstrating links between food availability and larval abundance is readily available (Leggett and DeBlois 1994; Cowan and Shaw 2002), predation during the larval period is also an important source of mortality and a primary cause of recruitment variability for many species (Houde 1987, 1989).

While mortality during the larval or pre-settlement stage may have large-scale impacts on recruitment of estuarine and marine fishes, post-settlement processes in

This thesis follows the style of Estuaries. 
nursery grounds often result in fine-scale adjustments to year class strength (Iles and Beverton 2000). Beck et al. (2001) defined an area as a nursery if a "species occurred at higher densities, avoided predation, and had higher growth rates compared to other habitats." Rapid growth allows juveniles to move out of size-selective predation ranges and into less vulnerable stages (Houde 1987). Nursery grounds help foster rapid growth and improved survival through a combination of factors, the most important being highquality prey resources, refuge from predators, and suitable physicochemical conditions (e.g. temperature, salinity, dissolved oxygen) (Gibson 1994; Beck et al. 2001). Therefore, the productivity and quality of a nursery habitat is linked to many factors which vary spatially and temporally, and changes in conditions within a nursery may affect year class success (Beck et al. 2001).

Estuaries are vital nursery grounds for several finfish species, including southern flounder (Paralichthys lethostigma). Southern flounder are commercially important flatfish throughout the Gulf of Mexico, second to red snapper in price/weight in Texas markets (GSMFC 2000). In addition, southern flounder are sought by recreational fishers, especially during fall spawning runs when adults are especially vulnerable both to bank and boat fishermen. Due to high levels of exploitation over the last few decades, it is not surprising that abundance and total landings of southern flounder have been on the decline since the late 1980s (GSMFC 2000). In 1987 total landings in Texas (commercial and sport fishing) hit a peak at over 500,000 lbs; however, ten years later total landings were down to approximately 150,000 lbs (GSMFC 2000).

Identifying habitats and sites which serve as nurseries to the many flatfish species that recruit to estuaries in early life is critical to conservation and management efforts. 
Along the East coast of the United States, several studies indicated that both abiotic and biotic controls of flatfish populations vary over the species range and that collection of more data on temperature, salinity, substrate, food availability and predation in all ranges is needed (Burke et al. 1991; Miller et al. 1991; Burke 1995; Guindon and Miller 1995). Southern flounder have been found to settle on muddy substrate (Burke et. al. 1991), and higher settlement patterns on specific substrates are common among flatfishes (stone flounder, Malloy et al. 1996; yellowfin sole and Alaskan plaice, McConnaughey and Smith 2000; winter flounder, Stoner et al. 2001; and summer flounder, Burke et al. 1991). Apart from substrate, patterns of habitat use for southern flounder and other congeners appear linked to salinity, with densities of post-settlers often higher in low-salinity waters farthest from tidal inlets (Miller et al. 1991; Gibson 1994; Guindon and Miller 1995). Burke et al. (1991) suggested that low salinity waters may offer protection from stenohaline marine predators, as well as diminish numbers of freshwater predators. Drawing conclusions from either sediment type or salinity alone is cautioned because sediment type and salinity are often correlated with temperature and each other, making conclusions based solely on one of these characteristics problematic (Gibson 1994).

The purpose of the present study was to examine large-scale (site-specific) and smallscale (habitat-specific) variation in settlement of southern flounder in the Galveston Bay Estuary (GBE), and to evaluate the recruits' condition and growth jointly so that the value of different bays and habitats to southern flounder could be assessed. Several complementary approaches were used to determine the quality of areas occupied by newly settled southern flounder along the upper coast of Texas. Specifically, biochemical condition (RNA:DNA) and growth (otolith microstructure analysis) were 
used to measure the relative fitness of individuals because poor nutritional condition and slow growth are coupled to survival. Thus, these two measures were used in conjunction with density data to evaluate the relative value of areas occupied by post-settlement southern flounder. Two hypotheses were tested: $\mathrm{H}_{0,1}$ Post-settlement southern flounder settle non-selectively throughout the Galveston Bay Estuary (GBE), utilizing all bays and habitats within this complex to the same extent; $\mathrm{H}_{0,2}$ Condition and growth (proxy for nursery habitat quality) of post-settlement southern flounder does not vary significantly among bays or habitats within the GBE.

Specific objectives of this study:

1) Describe the general early-juvenile flatfish assemblage in the GBE;

2) Characterize settlement patterns of southern flounder at large scales (across bays) and small scales (across habitats within a bay) in the GBE;

3) Determine the age, hatch-date distribution, and growth of postsettlement southern flounder in different bays and habitats within the GBE; and

4) Establish the habitat quality of different areas inhabited by postsettlement southern flounder in the GBE using measures of biochemical condition and recent growth. 


\section{METHODS}

\section{Field Work}

The GBE was separated into three main areas for study: East Bay, Galveston Bay, and West Bay (Fig. 1). East Bay is the eastern portion of the estuary and is connected to the Gulf of Mexico at Rollover Pass. Galveston Bay consists of sites in the central, core portion of the estuary, with water flow through Bolivar Roads (main entrance to estuary and shipping lanes). West Bay is located in the far western portion of GBE, with its main input of water from San Luis Pass. In each bay, three sites were randomly chosen for repeated sampling: East Bay (site 1: $29^{\circ} 26.96 \mathrm{~N}, 94^{\circ} 41.85 \mathrm{~W}$; site $2: 29^{\circ} 29.14 \mathrm{~N}$, $94^{\circ} 36.23 \mathrm{~W}$; site $3: 29^{\circ} 31.86 \mathrm{~N}, 94^{\circ} 33.72 \mathrm{~W}$ ), Galveston Bay (site 1: 29⒛70N, $94^{\circ} 49.37 \mathrm{~W}$; site $2: 29^{\circ} 18.24 \mathrm{~N}, 94^{\circ} 56.68 \mathrm{~W}$; site $\left.3: 29^{\circ} 15.30 \mathrm{~N}, 94^{\circ} 55.15 \mathrm{~W}\right)$, West Bay (site $1: 29^{\circ} 02.73 \mathrm{~N}, 95^{\circ} 10.51 \mathrm{~W}$; site $2: 29^{\circ} 02.04 \mathrm{~N}, 95^{\circ} 11.71 \mathrm{~W}$; site $3: 29^{\circ} 03.87 \mathrm{~N}$, $\left.95^{\circ} 10.03 \mathrm{~W}\right)$. Collections were taken monthly during the primary recruitment period for southern flounder (January to May 2005). Data from preliminary sampling in 2004 were not included in this analysis due to low numbers collected of newly settled southern flounder ( $\mathrm{n}=30$; Appendix 1). Each site (9 total) was sampled with a $1 \mathrm{~m}(\mathrm{~W}) \times 0.5 \mathrm{~m}$ (H) beam trawl fitted with a $1 \mathrm{~mm}$ mesh net attached. Three habitat types were sampled in replicates of three: 1) marsh edge, 2) intermediate zone (10-20m from marsh interface; $\sim 1 \mathrm{~m}$ depth), and 3) bay zone (depth $>1 \mathrm{~m}$; typically $>100 \mathrm{~m}$ from marsh interface). In marsh edge and intermediate zones, the net was fitted with two 20-m ropes, researchers walked in an arc away from the path of the net, and then pulled the net to themselves by hand. In the bay zone, the net was attached to a bridle rope $(10 \mathrm{~m})$, which 


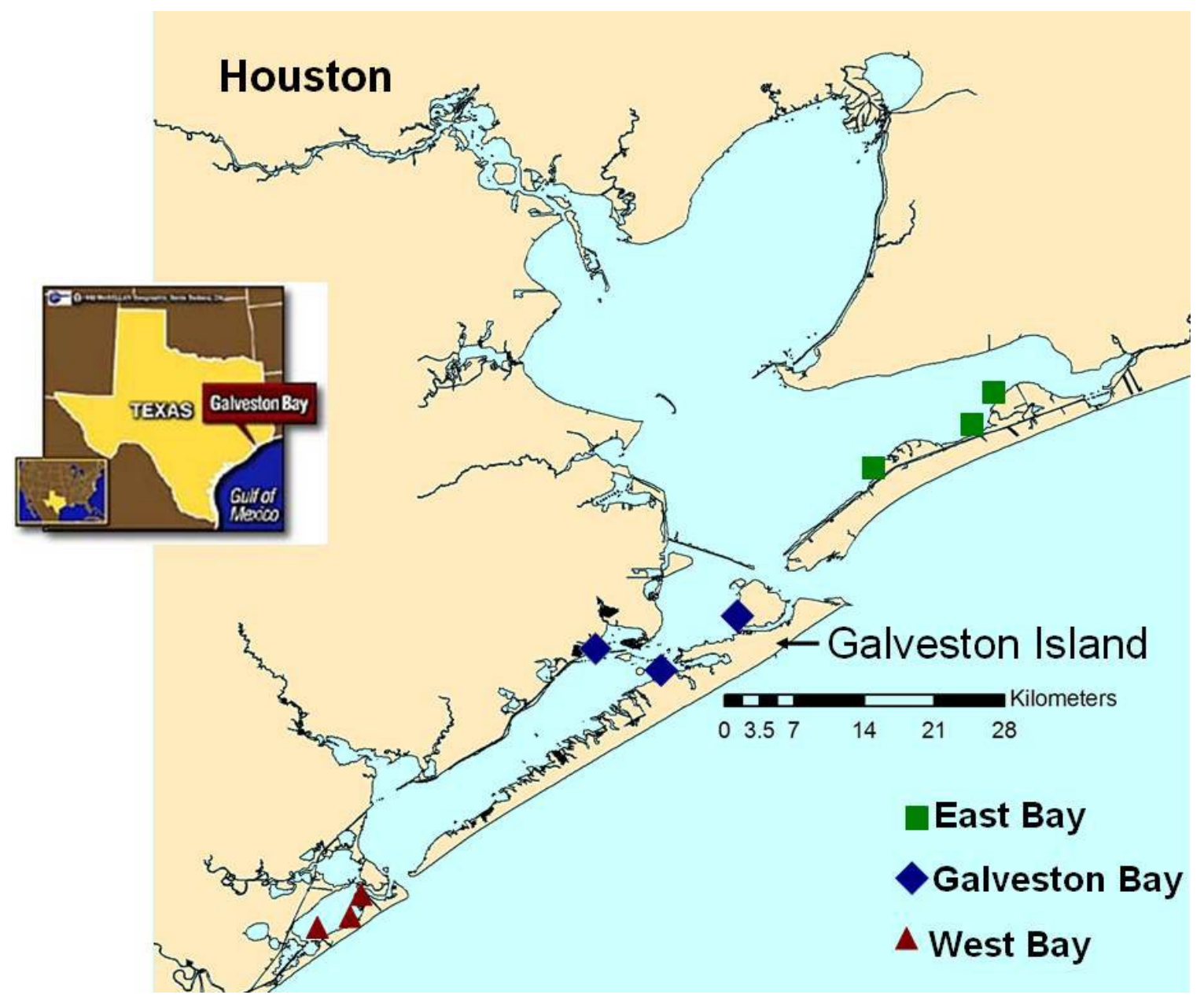

Figure 1. Map of study area and sampling sites in the Galveston Bay Estuary. 
was then attached to the back of a boat. The net was pulled at approximately $3.5 \mathrm{~km} \mathrm{~h}^{-1}$ for $2 \mathrm{~min}$, and start and stop GPS locations were recorded for each tow to determine exact location and distance covered. Measurements of temperature, salinity, and DO were taken at each site in the field. These sampling activities occurred between the hours of 9 AM and 5 PM.

\section{Laboratory Work}

\section{Condition}

Condition of juvenile fish can be determined by a variety of biochemical means by quantifying components of energy substrates or calculating physiological rate indicators, such as proteins, lipids, digestive enzymes, and nucleic acids (Ferron and Leggett 1994). The relationship between the constant quantity of DNA in a cell and the quantity of RNA, which fluctuates with protein synthesis rate, can be linked to growth since growth is achieved through protein synthesis (Buckley et al. 1984; Ferron and Leggett 1994). RNA:DNA ratios reflect recent growth conditions (2-4 days preceding capture) and thus can be connected to environmental measures taken concurrent with sampling (Buckley 1984; Bulow 1987; Ferron and Leggett 1994). This approach has been used successfully to characterize the nutritional status of estuarine fishes (Westerman and Holt 1988; Imsland et al. 2002) including flounder (Gwak and Tanaka 2002).

In the present study, sections of trunk muscle tissue were extracted from frozen juvenile southern flounder for RNA:DNA analysis. Only a subset of southern flounder were analyzed from one sampling period (month: February) to reduce potential effects of temporal variation. Analysis was conducted at the University of Texas Fisheries and 
Mariculture Laboratory at Port Aransas, TX, following the ethidium bromide flourometric procedures described by Westerman and Holt (1988). Individual trunk muscle samples were homogenized, and aliquots of homogenates $(25-100 \mu 1)$ were used to estimate DNA and RNA concentrations. Calculations were based on comparisons with DNA-EB and RNA-EB calibration curves from known standards. Calf thymus DNA and yeast RNA (type III) were used as standards. Also, aliquots were used for total soluble protein concentration using Bicinchoninic Acid Protein Assay Kit (Sigma product). Age and Growth

Examination of otoliths is a technique to determine age and long-term growth rates of individuals (Campana and Neilson 1985). Annual layers, or annuli, are formed at a constant, consistent frequency and can be counted for age in years, and distances between successive annuli can be interpreted as being proportional to changes in body size (Campana and Neilson 1985). Also, the otoliths of young fishes form daily checks, or circuli (Pannella 1971). Fitzhugh and Rice (1995) determined that southern flounder during the first year of life produce daily otolith growth increments that can be seen under a microscope. Age and growth of southern flounder based on otolith structure has been used in several studies (Fitzhugh et al. 1996; Stunz et al. 2000; Fischer and Thompson 2004).

Upon the completion of standard length measurements of southern flounder, sagittal otoliths were removed and cleaned with one of the pair randomly selected for aging. The selected otolith was mounted on a slide and polished to the core on each side using Buehler Carbimet paper discs $(320,400,600,800$, and 1200 grit) and $0.3 \mu \mathrm{m}$ alumina polishing compound following procedure outlined by McCurdy et al. (2002). 
Polished sections were examined using an Olympus BX41 compound microscope with analysis aided by Image Pro Plus 4.5 software. Daily growth increments of all otoliths were counted by one reader with a subset counted by a second reader for quality control. Otolith counts that were not within $10 \%$ agreement with one another were counted a third time to try to resolve the difference; if it was not resolved, then it was not included for analysis. Otoliths that were considered unreadable (due to cracking, polishing error, or position in epoxy) and otoliths ruined by epoxy drying were also discarded. Of all southern flounder collected, 54\% $(n=101)$ were assigned age, $24 \%$ were deemed unreadable due to polishing error (including cracking that might have occurred during polishing), $14 \%$ were unreadable or lost due to epoxy problems, and $10 \%$ were deemed unuseable due to structure of otolith or count disagreement. Growth rates (daily instantaneous) were determined by fitting an exponential model to size-at-age plots:

$$
\mathrm{L}_{\mathrm{t}}=\mathrm{L}_{0} \mathrm{e}^{\mathrm{gt}}
$$

where $\mathrm{L}_{\mathrm{t}}=$ length (mm standard length) at time $\mathrm{t}, \mathrm{L}_{0}=$ estimated length at hatching, $\mathrm{g}=$ instantaneous growth coefficient, and $\mathrm{t}=$ estimated age (days after hatching). Also, growth increment widths between days 30 to 40 were measured to estimate recent growth in a subset of individuals. The most recent 10 increments were not counted because clarity around the edges of the otoliths was poor. Hatchery-reared southern flounder of known age from The University of Texas Marine Science Institute were used to validate daily increment deposition.

\section{Data Analysis}

Analysis of variance (ANOVA) tested the main effects of area, site, and habitat type on the density of southern flounder. Data from April were not included in the 
analysis because only one southern flounder was caught during this period. Date was used as a blocking factor. Instantaneous growth rates of juvenile southern flounder were estimated as slope of standard length regressed on age estimated from otolith analysis.

Analysis of covariance (ANCOVA) was used to investigate effects of bay and habitat on RNA:DNA ratios and growth. The covariate in all ANCOVA models was standard length. Alpha level was set at 0.05 . 


\section{RESULTS}

\section{Environmental Conditions}

Salinity varied both spatially and temporally within the GBE. Mesohaline conditions typically were observed in East Bay (mean range: 9-13 ppt), but conditions within the central portion of Galveston Bay (15-25 ppt) and West Bay (20-31 ppt) were essentially polyhaline (Table 1). Significant differences in salinity occurred among bays (ANOVA, $\mathrm{p}<0.001$ ) and among months (ANOVA, $\mathrm{p}<0.001$ ) with a bay*month interaction (ANOVA, $\mathrm{p}<0.001$ ); however, salinity did not vary among habitat types (ANOVA, $\mathrm{p}=0.735$ ). Tukey HSD test indicated that East Bay had significantly lower salinity than both Galveston Bay and West Bay and that all bays were significantly different from one another. Temperature also varied significantly among bays (ANOVA, $\mathrm{p}=0.003)$ and among months (ANOVA, $\mathrm{p}<0.001)$ with the bay*month interaction included in the model (ANOVA, $\mathrm{p}<0.001$ ); but, temperature did not vary as a function of habitat type (ANOVA, $\mathrm{p}=0.632$ ). Tukey HSD test indicated that East Bay (mean $16.8^{\circ} \mathrm{C}$ ) had significantly lower temperatures than both Galveston Bay (mean $17.0^{\circ} \mathrm{C}$ ) and West Bay (mean $18.5^{\circ} \mathrm{C}$ ), with no difference in temperature between Galveston Bay and West Bay. Dissolved oxygen (DO) levels (during the diurnal period) were not significantly different among bays (ANOVA, $\mathrm{p}=0.582)$ but were significantly different among months (ANOVA, $\mathrm{p}=0.003$ ) with no bay*month interaction (ANOVA, $\mathrm{p}=$ 0.061). Tukey HSD test indicated that January $(9.94 \mathrm{mg} / \mathrm{mL})$ and February $(9.41 \mathrm{mg} / \mathrm{mL})$ had higher DO levels than April $(7.82 \mathrm{mg} / \mathrm{mL})$. In contrast to salinity and temperature, DO varied among habitat types in the GBE (ANOVA, $\mathrm{p}<0.001$ ); higher DO concentrations were found in the marsh edge and intermediate zones than in the bay zone. 
Table 1. Environmental parameters (salinity, temperature, and dissolved oxygen) from three regions of Galveston Bay Estuary in 2005. Estimates are mean value ( $\pm 1 \mathrm{SE}$ ) of the three sites surveyed within each bay. Salinity is reported in ppt, temperature in ${ }^{\circ} \mathrm{C}$, and dissolved oxygen in $\mathrm{mg} / \mathrm{L}$.

\begin{tabular}{|c|c|c|c|c|}
\hline \multirow{4}{*}{$\begin{array}{l}\text { Salinity } \\
\text { ppt } \\
\text { East Bay } \\
\text { Galveston Bay } \\
\text { West Bay } \\
\end{array}$} & January & February & March & April \\
\hline & $12( \pm 0.61)$ & $13( \pm 0.76)$ & $9( \pm 0.0 .40)$ & $13( \pm 1.42)$ \\
\hline & $19( \pm 0.68)$ & $16( \pm 1.63)$ & $15( \pm 1.21)$ & $25( \pm 1.29)$ \\
\hline & $25( \pm 0.58)$ & $22( \pm 0.33)$ & $20( \pm 0.50)$ & $31( \pm 0.40)$ \\
\hline \multicolumn{5}{|l|}{ Temperature } \\
\hline East Bay & $13.4( \pm 0.99)$ & $15.1( \pm 0.50)$ & $16.8( \pm 1.65)$ & $21.9( \pm 0.78)$ \\
\hline Galveston Bay & $17.1( \pm 0.92)$ & $18.1( \pm 0.53)$ & $16.6( \pm 0.84)$ & $22.7( \pm 0.42)$ \\
\hline West Bay & $18.9( \pm 0.66)$ & $13.1( \pm 0.22)$ & $18.3( \pm 0.36)$ & $23.7( \pm 0.28)$ \\
\hline \multicolumn{4}{|c|}{ "Dissolved Oxygen } & April \\
\hline East Bay & $10.02( \pm 0.25)$ & $8.95( \pm 0.67)$ & $7.97( \pm 0.47)$ & $7.57( \pm 0.46)$ \\
\hline Galveston Bay & $10.43( \pm 0.58)$ & $9.92( \pm 2.29)$ & $9.78( \pm 0.45)$ & $7.87( \pm 0.54)$ \\
\hline West Bay & $9.93( \pm 0.44)$ & $9.53( \pm 1.06)$ & $8.88( \pm 0.58)$ & $8.03( \pm 0.66)$ \\
\hline
\end{tabular}




\section{Distribution and Abundance}

Spatial variation in the assemblage of larval and early-juvenile flatfish present in GBE in 2005 was investigated. A total of 573 individuals was collected from four different species: 335 bay whiff (Citharichthys spilopterus), 184 southern flounder (Paralichthys lethostigma), 50 blackcheek tonguefish (Symphurus plagiusa), and 4 fringed flounder (Etropus crossotus) (Fig. 2). In East Bay, southern flounder made up $54 \%$ of the overall catch, with bay whiff making up $31 \%$ of the catch. In Galveston Bay, bay whiff was the dominant flatfish accounting for $65 \%$ of the catch, compared to $28 \%$ for southern flounder. Bay whiff also dominated by number and percentage $(90 \%)$ in West Bay, with southern flounder making up only $7 \%$ of the catch. Most southern flounder (82\%) collected in GBE were caught in January and February, while most bay whiff (68\%) were caught in March and April. Fringed flounder were only caught in the month of February and made up $<1 \%$ of the flatfish assemblages in the three bays. Blackcheek tonguefish were caught primarily in East Bay (82\%), and over 70\% were caught in January and February.

Density of southern flounder recruits in GBE varied by time and location, and settlement began at approximately $9 \mathrm{~mm}$ (Fig. 3). The catch was dominated by individuals between 12 and $19 \mathrm{~mm}$, with the majority of southern flounder collected from East Bay (77\%). Densities of southern flounder ranged from zero in some habitats and months to a maximum of 21.7 per $100 \mathrm{~m}^{2}$. Significantly higher densities of southern flounder were found in East Bay relative to West Bay and Galveston Bay (ANOVA, $\mathrm{p}=$ 0.006) (Fig. 4). Sample numbers in East Bay were sufficient to enable 

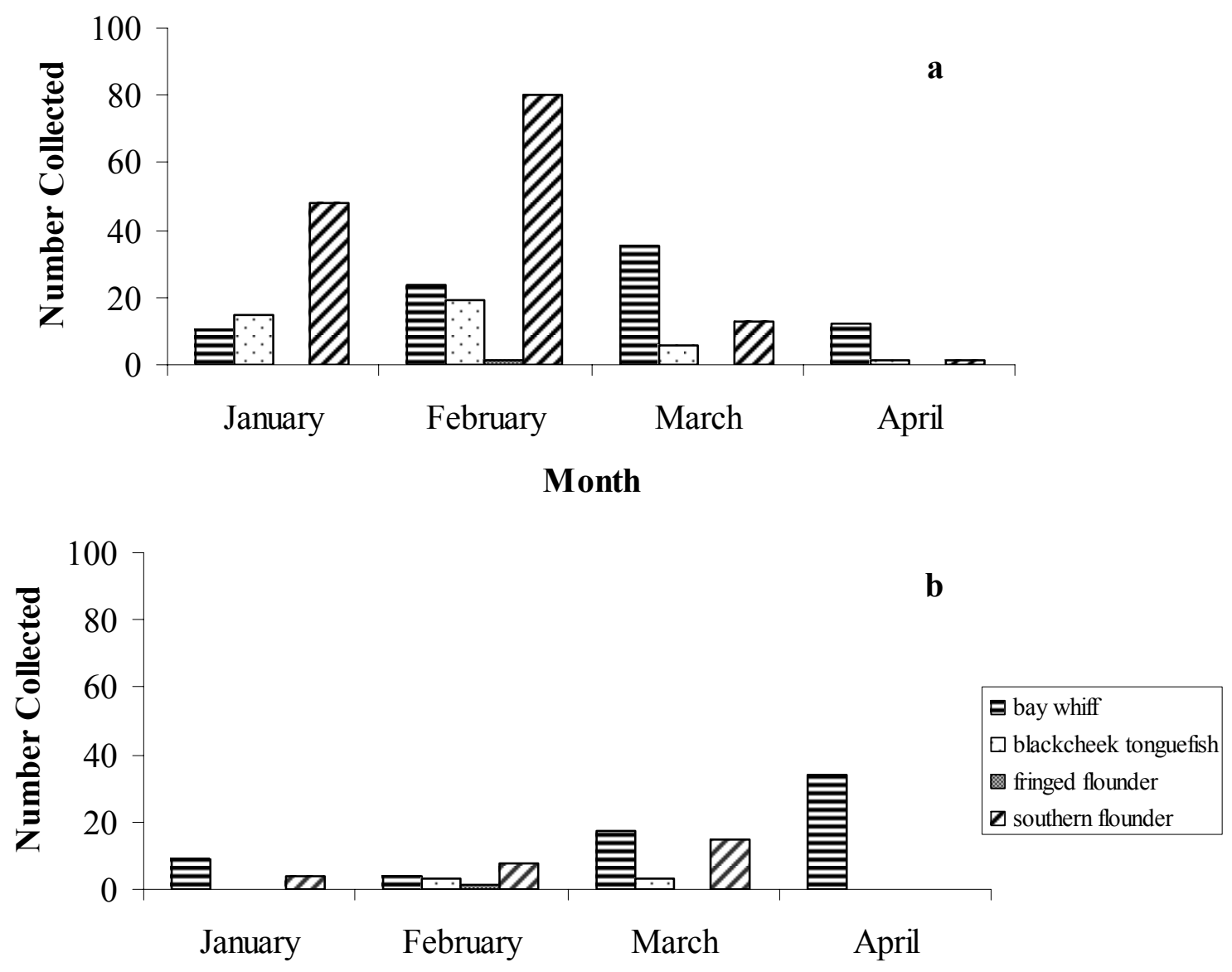

Month

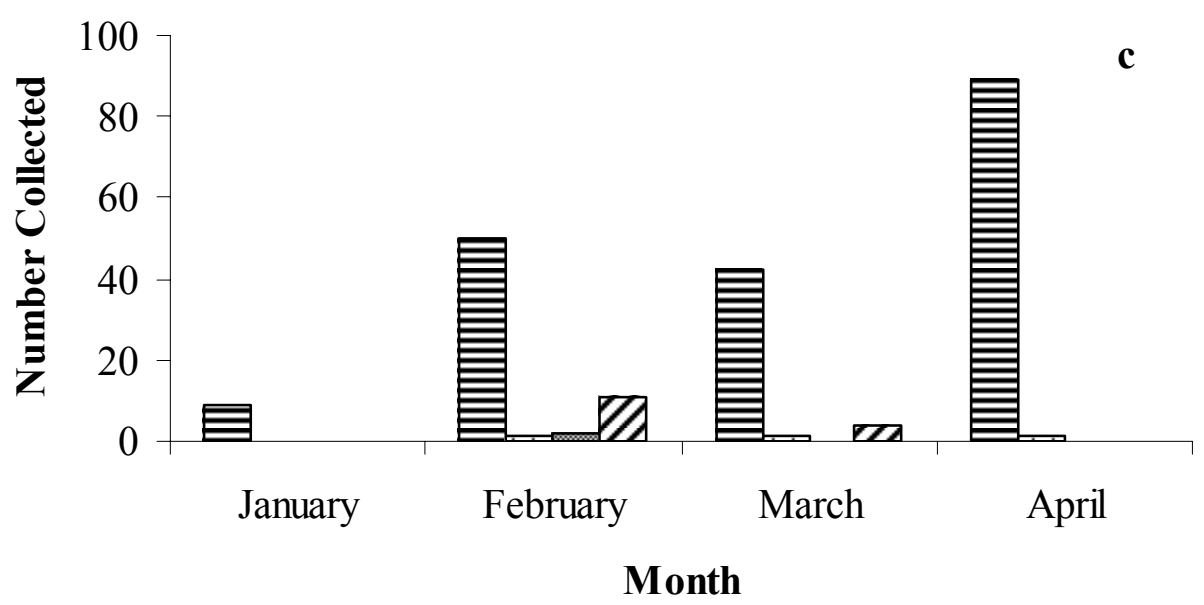

Figure 2. Seasonal variation in the number of larval or juvenile flatfishes (bay whiff, blackcheek tonguefish, fringed flounder, and southern flounder) from the Galveston Bay Estuary in 2005. Data are divided by bay: a) East Bay, b) Galveston Bay, and c) West Bay. 

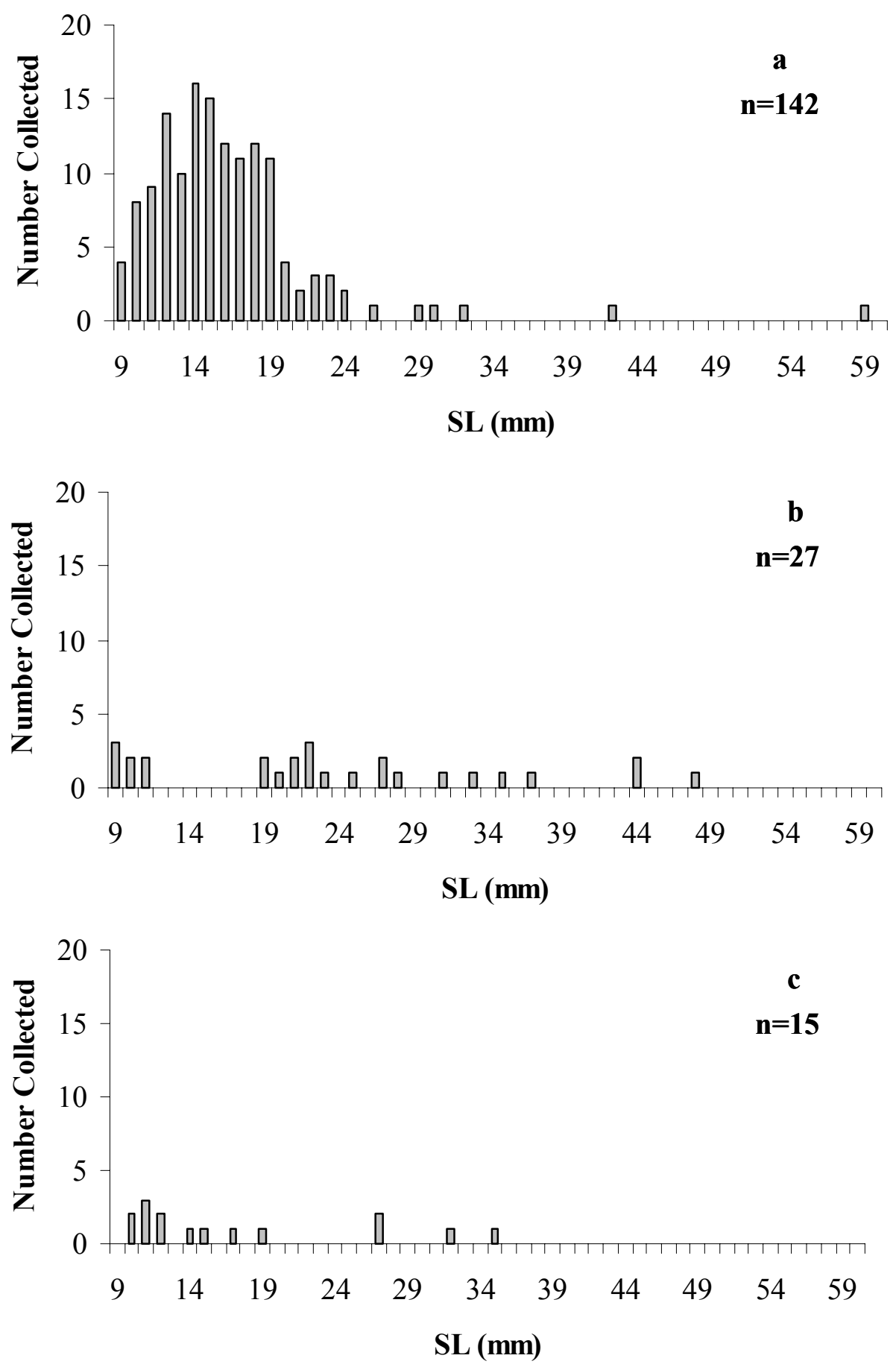

Figure 3. Length-frequency distributions of newly settled southern flounder from the Galveston Bay Estuary in 2005. Data are divided by bay: a) East Bay, b) Galveston Bay, and c) West Bay. 

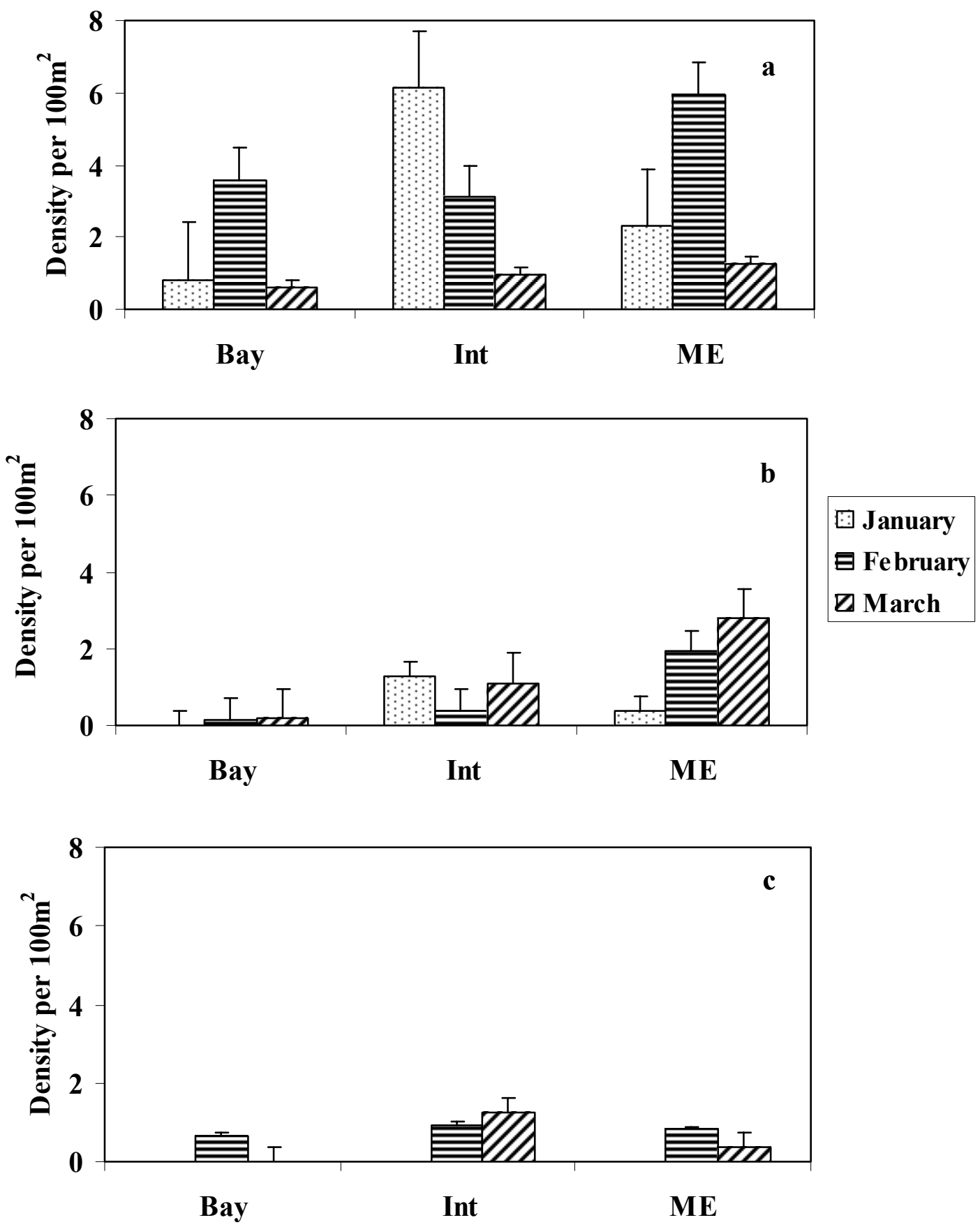

Figure 4. Densities (number per $100 \mathrm{~m}^{2}$ ) of newly settled southern flounder from the Galveston Bay Estuary in 2005. Estimates of density are given by habitat and data are divided by bay: a) East Bay, b) Galveston Bay, and c) West Bay. Error bars represent 1 SE. Habitat codes: Bay = bay zone, Int $=$ intermediate zone, $\mathrm{ME}=$ marsh edge. 
investigation of specific patterns of habitat use. Southern flounder densities in the bay-

zone habitat $\left(1.7\right.$ per $\left.100 \mathrm{~m}^{2}\right)$ tended to be lower than in the intermediate $\left(3.4\right.$ per $\left.100 \mathrm{~m}^{2}\right)$

or marsh-edge (3.2 per $100 \mathrm{~m}^{2}$ ) habitats; however, no significant difference was detected (ANOVA, $p=0.404)$. Month collected was not significant (ANOVA, $p=0.065)$, but densities tended to be higher in January $\left(1.2\right.$ per $\left.100 \mathrm{~m}^{2}\right)$ and February $\left(1.9\right.$ per $\left.100 \mathrm{~m}^{2}\right)$ than in March (0.95 per $\left.100 \mathrm{~m}^{2}\right)$.

\section{Condition}

Estimates of biochemical condition were limited to samples from the same month of collection (February), to minimize temporal effects (e.g., changes in temperature and associated variables). The average RNA:DNA ratio was 9.17 (range: 6.34 to 15.19), and RNA:DNA ratio did not vary with standard length of southern flounder (ANCOVA, $\mathrm{p}=$ 0.52) (see Appendix 1). Based on a previous laboratory validation study that quantified RNA:DNA ratios of well-fed and starved southern flounder reared at a constant temperature of $18^{\circ} \mathrm{C}$ and salinity of $31 \mathrm{ppt}$ (G. Joan Holt, unpublished data), over $90 \%$ of the assayed southern flounder from the GBE matched the "well fed" signature (Fig. 5). A significant difference in RNA:DNA ratios was detected among bays (ANOVA, $\mathrm{p}=$ 0.003). West Bay had lower RNA:DNA ratios (mean 8.0 SE \pm 0.3 ) than East Bay (mean 9.5 $\mathrm{SE} \pm 0.2$ ) and Galveston Bay (mean 9.8 SE \pm 0.4 ) (Fig. 6). Tukey HSD test showed that West Bay had significantly lower ratios than both East Bay and Galveston Bay, but there was no difference between East Bay and Galveston Bay. RNA:DNA ratios did not vary by habitat within bay (ANOVA, $p=0.114$ ) and no interaction was detected for bay*habitat (ANOVA, $\mathrm{p}=0.632$ ). 


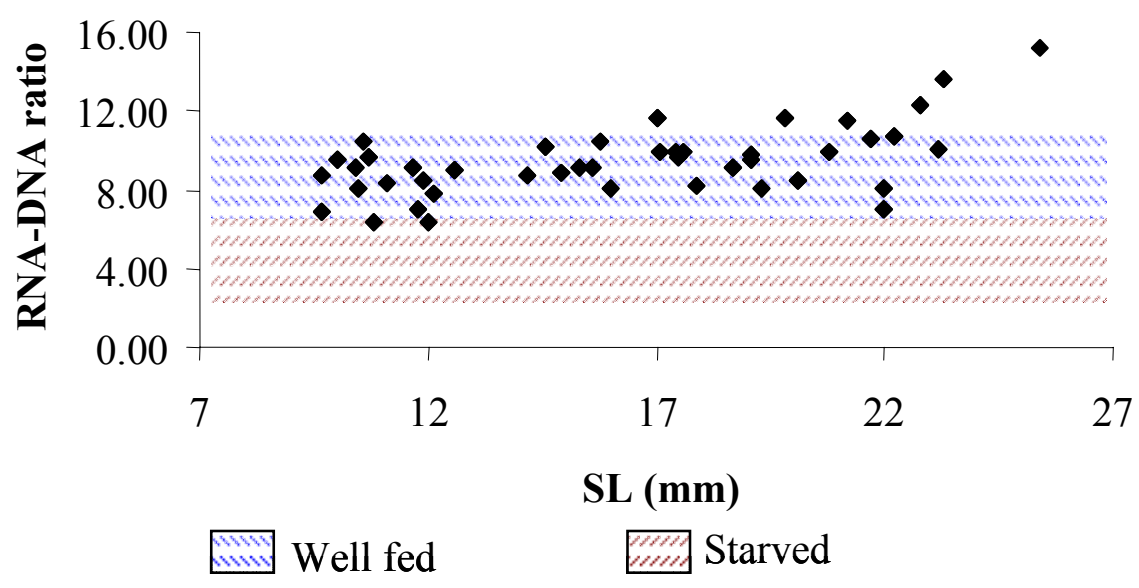

Figure 5. RNA:DNA ratios of newly settled southern flounder from the Galveston Bay Estuary in 2005. Estimates are shown in relation to predicted conditions for well-fed and starved southern flounder from laboratory trials (G. Joan Holt, unpublished data). 


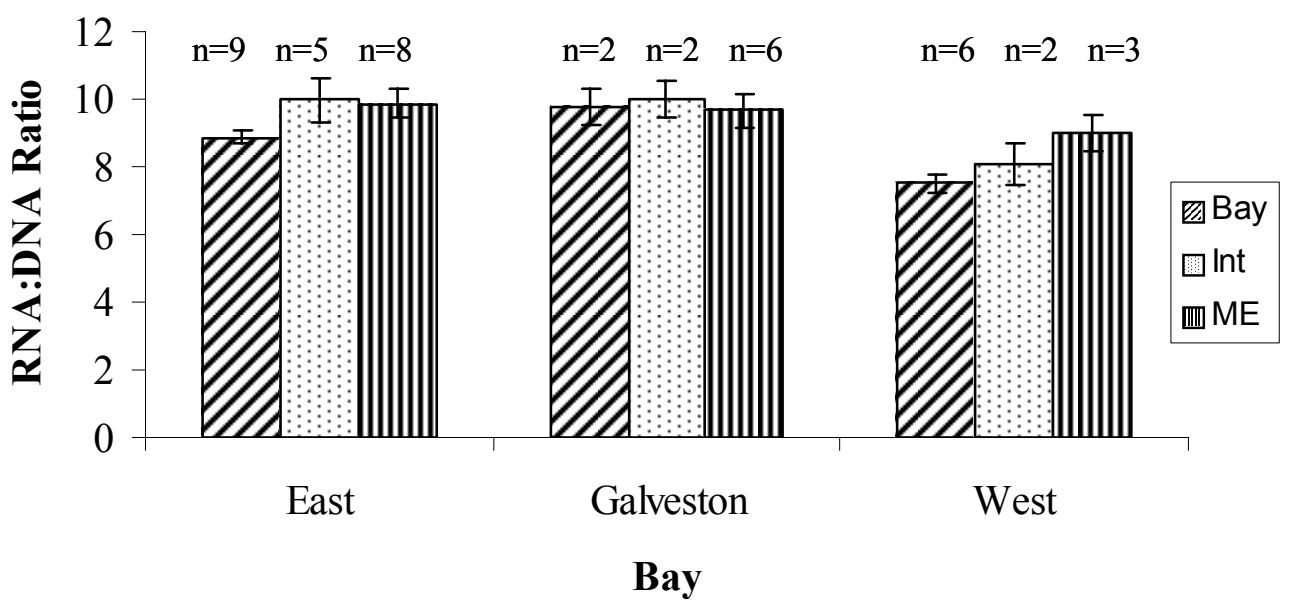

Figure 6. Mean RNA:DNA ratios for newly settled southern flounder from the Galveston Bay Estuary in 2005. Ratios are given by bay and habitat. Error bars represent $1 \mathrm{SE}$. Habitat codes: Bay = bay zone, $\mathrm{Int}=$ intermediate zone, $\mathrm{ME}=$ marsh edge. 


\section{Age and Growth}

Otolith-based estimates of age indicated that southern flounder collected in GBE ranged in age from 27 days old to 78 days old (Fig. 7). Otoliths from 101 individuals were aged; however, for the growth-curve analysis only 100 individuals were used, because length data on one individual had been lost. Over half of the southern flounder aged (53\%) were between 35-45 days old. Recruitment of southern flounder to the GBE occurred in a single mode, with a peak in hatch-dates from December 9 thru January 12 (Fig. 8). Hatch-date distributions of individuals collected in East Bay and Galveston Bay were protracted (early December to February), while recruits from West Bay were derived from a limited hatch-date distribution (December 31 to January 11).

Overall growth of southern flounder (all bays combined) was adequately described by the exponential model: $\mathrm{SL}(\mathrm{mm})=5.519 \mathrm{e}^{0.0253^{*} \text { age-in-days }}$ with an $\mathrm{R}^{2}=0.581$ (Fig. 9). Growth rates were $0.24 \mathrm{~mm} \mathrm{~d}^{-1}$ (21-30 days old), $0.31 \mathrm{~mm} \mathrm{~d}^{-1}$ (31-40 days old), $0.40 \mathrm{~mm} \mathrm{~d}^{-1}$ (41-50 days old), and $0.51 \mathrm{~mm} \mathrm{~d}^{-1}$ (51-60 days old), with an average growth rate of $0.40 \mathrm{~mm} \mathrm{~d}^{-1}$. Although sample sizes were small, habitat- (within East Bay) and bay-specific growth rates were examined; no effect was observed for either habitat $($ ANCOVA, $p=0.436$, power $=0.189)$ or bay $($ ANCOVA, $p=0.514$, power $=0.160)$ (Fig. 10). Southern flounder were divided into cohorts by hatch-date (December and January) and no significant differences were present between cohorts (ANCOVA, $\mathrm{p}=$ 0.172 , power $=0.276)($ Fig. 11)

In addition to comparing overall growth for the entire pre-settlement/postsettlement period, recent growth estimates were obtained by measuring widths of outer growth increments (corresponds to growth from 30-40 days) on a subset of otoliths 


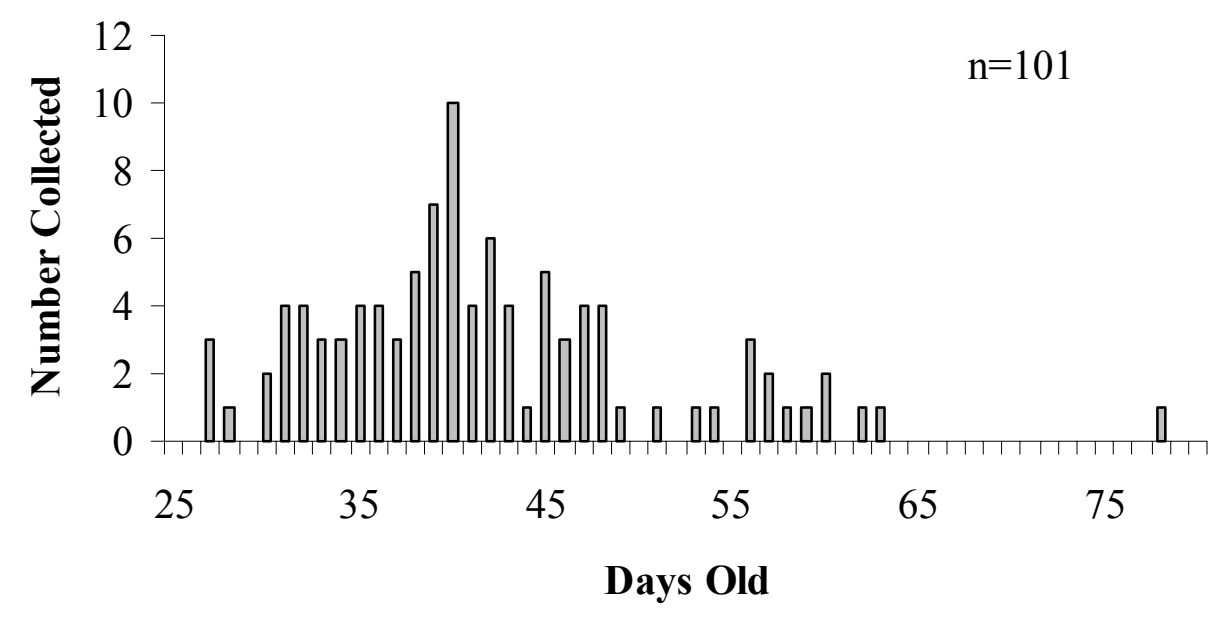

Figure 7. Age-frequency distribution of newly settled southern flounder from the Galveston Bay Estuary in 2005. 


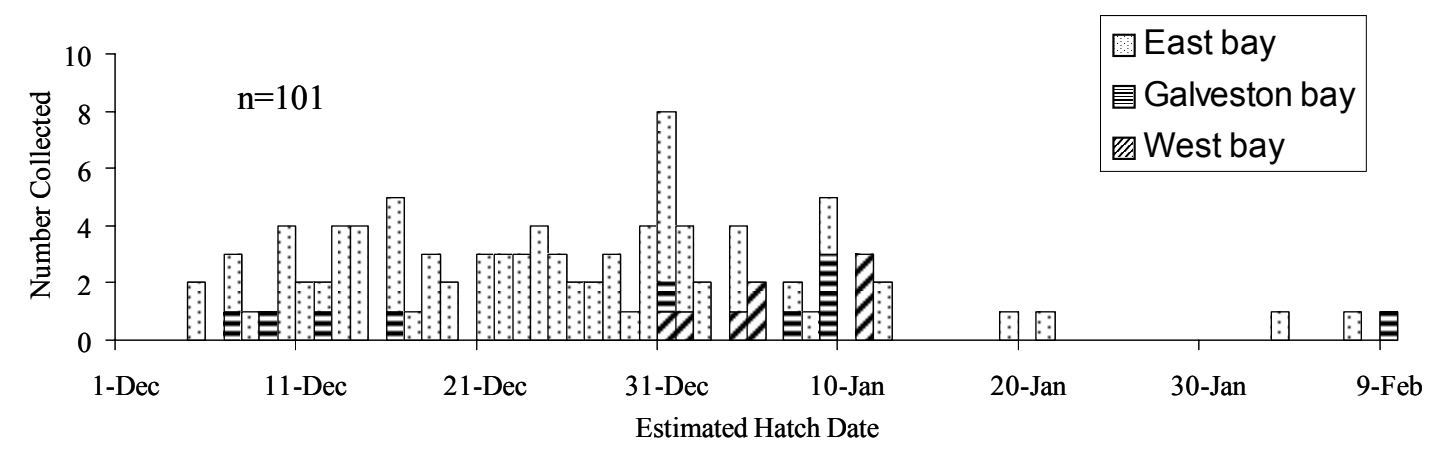

Figure 8. Hatch-date distribution of newly settled southern flounder from the Galveston Bay Estuary in 2005. Data are coded by bay. 


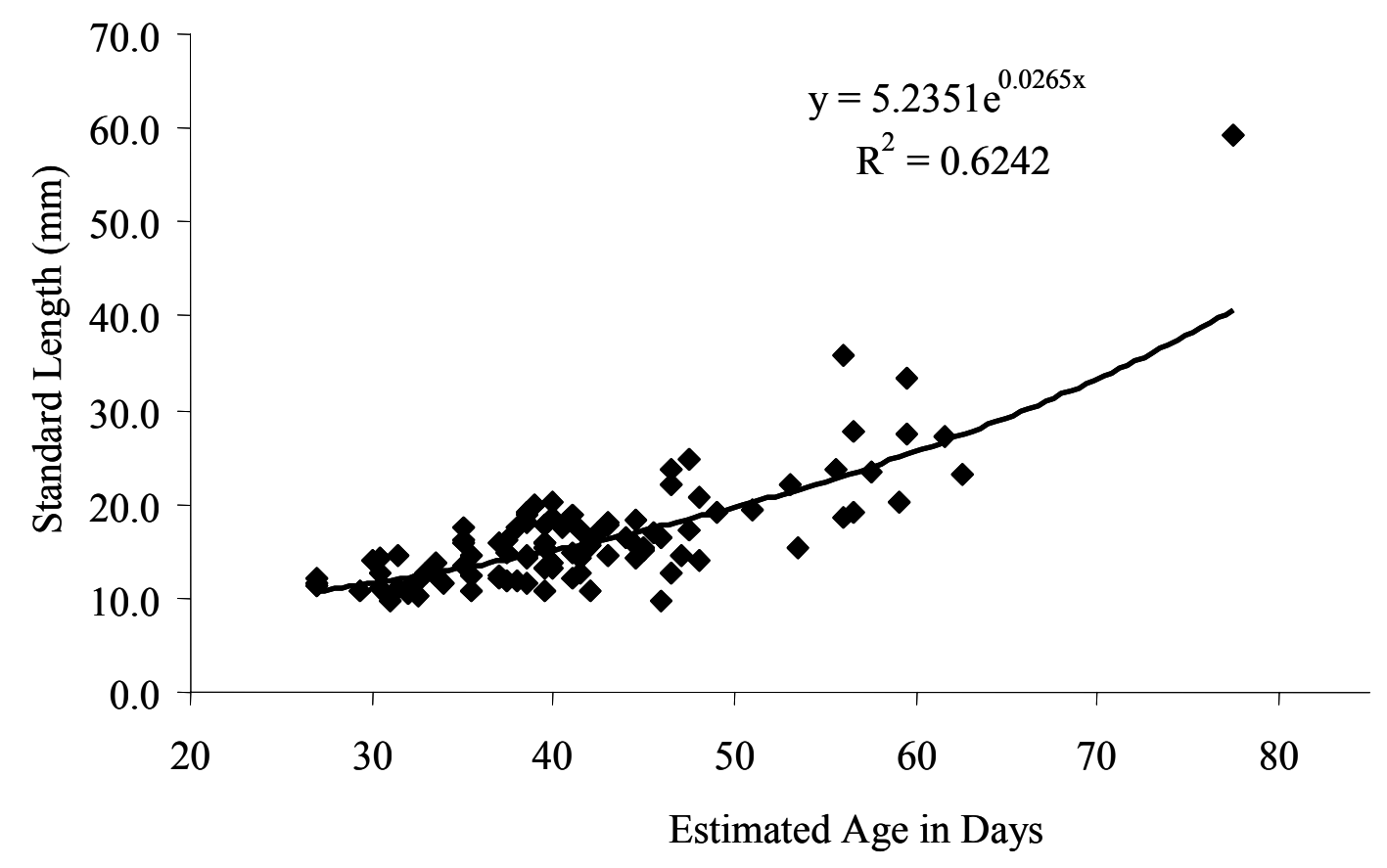

Figure 9. Size-at-age relationship for newly settled southern flounder from the Galveston Bay Estuary (all sites pooled) in $2005(\mathrm{n}=100)$. Exponential growth equation is given. 


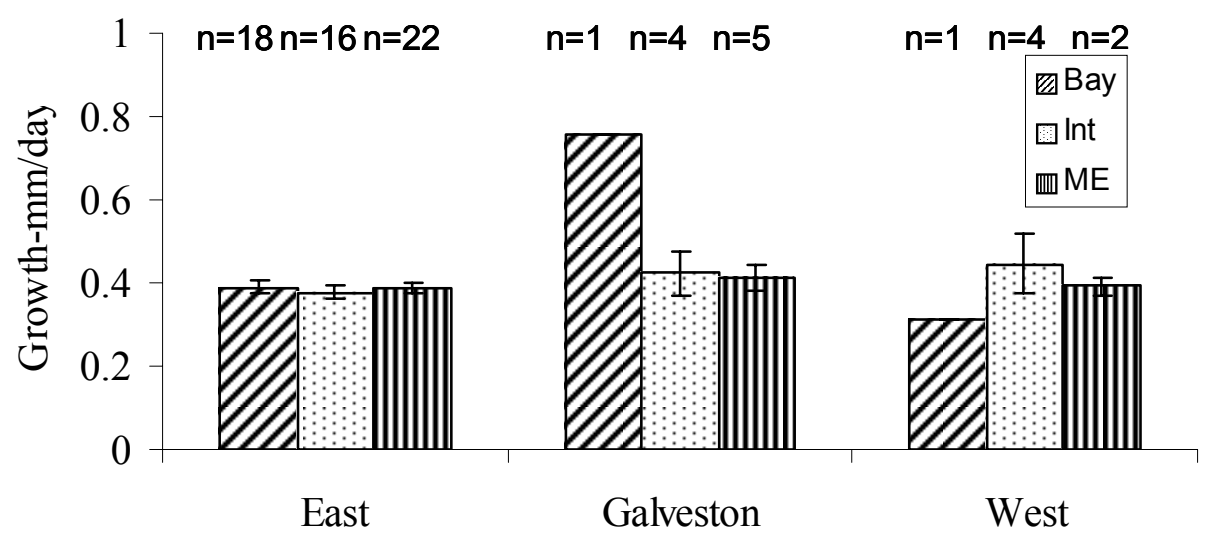

Figure 10. Mean growth rates ( $\mathrm{mm} /$ day) of newly settled southern flounder from the Galveston Bay Estuary in 2005. Estimates are given by bay and by habitat. Error bars represent $1 \mathrm{SE}$. Habitat codes: Bay $=$ bay zone, $\mathrm{Int}=$ intermediate zone, $\mathrm{ME}=$ marsh edge. 


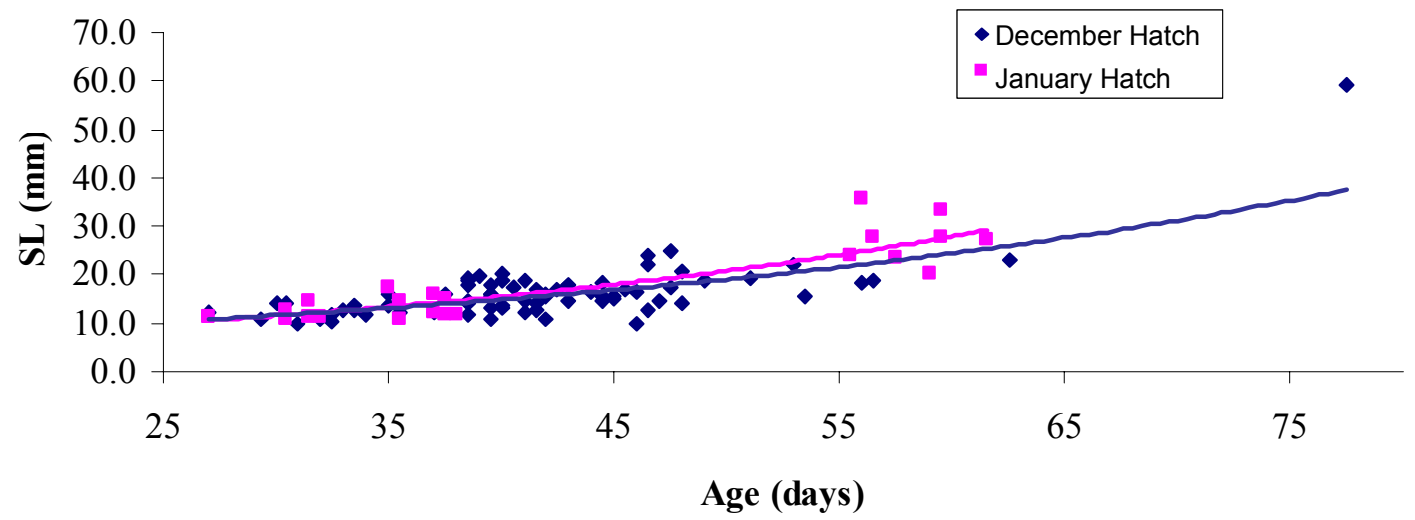

Figure 11. Growth rates of newly settled southern flounder collected from the Galveston Bay Estuary in 2005, separated into hatch-date cohorts (December and January). 
representing each bay (all habitats pooled for each bay). Mean estimates of recent otolith growth were highest for southern flounder from West Bay (59.6 microns) and slightly lower in Galveston Bay (53.8 microns). The lowest estimates of recent growth were observed in East Bay (44.1 microns). Despite the trend, no significant difference in recent growth was detected among bays (ANOVA, $\mathrm{p}=0.145$, power $=0.383$ ) or among habitats; nor, did SL vary significantly (ANCOVA, p=0.392) (Fig. 12). 


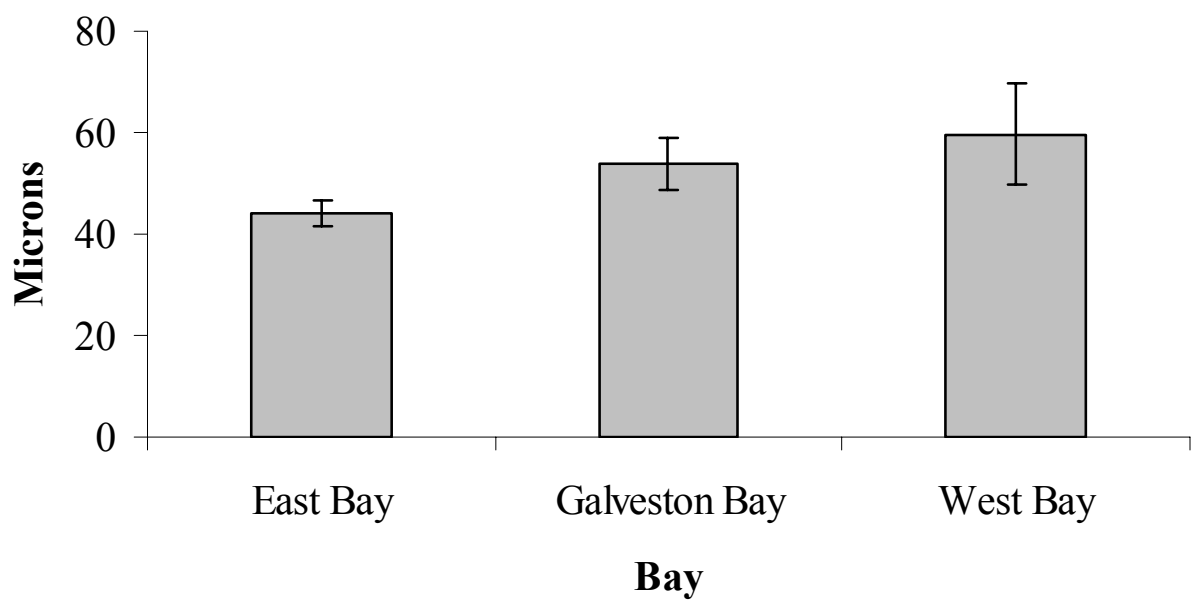

Figure 12. Recent growth of newly settled southern flounder from the Galveston Bay Estuary in 2005. Estimates represent the mean otolith width (microns) from increment 30 to 40. Mean values are given by bay and error bars represent $1 \mathrm{SE}$. 


\section{DISCUSSION}

Bay whiff and southern flounder were the dominant juvenile flatfishes collected in the Galveston Bay Estuary (GBE) during the winter 2005 sampling period (58\% and $32 \%$ of total catch, respectively). In addition, small numbers of juvenile blackcheek tonguefish and fringed flounder were present. The observed flatfish assemblage was consistent with expectations based on presumed winter spawning periods of flatfishes in the Gulf of Mexico (Hoese and Moore 1998; McEachran and Fechhelm 2006); however, comparisons with other estuaries suggest that some regional differences occur. Allen and Baltz (1997) observed all four species in a nearby Louisiana estuary and reported that offshore tonguefish (Symphurus civitatium) and bay whiff comprised almost $80 \%$ of the flatfish catch, with lower numbers of southern flounder, blackcheek tonguefish, and fringed flounder. In addition, several other species of flatfish were collected including lined sole (Achirus lineatus) and hogchoker (Trinectes maculates). Taxa observed in both Texas and Louisiana estuaries also occur in the northeastern Gulf, where increased catches of juvenile Gulf flounder (Paralichthys albigutta) have been reported (Ginsburg 1952; Topp and Hoff 1972; Nall 1979). Although no juvenile Gulf flounder were collected in the present study, they do occur in the region, albeit in lower numbers than in Florida (Hoese and Moore 1998).

On the East coast of the U.S., all four flatfish taxa collected in the GBE have been observed but their relative abundances are markedly different. For example, Reichart and van der Veer (1991) reported catches of juvenile flatfishes from a Georgia estuary with fringed flounder dominating the catch numerically. High densities of bay whiff and 
blackcheek tonguefish were also present. Although southern flounder and two congeners were collected (summer flounder Paralichthys dentatus, and fourspot flounder Paralichthys oblongus), numbers were low (southern flounder $<0.5$ per $100 \mathrm{~m}^{2}$, summer flounder 0-7.9 per $100 \mathrm{~m}^{2}$, fourspot flounder $0-3.5$ per $100 \mathrm{~m}^{2}$ ). These congeners appear to co-occur in other estuaries on the eastern seaboard (Weinstein 1979; Burke et al 1991; Burke 1995; Able and Fahay 1998). Juvenile surveys suggest that southern flounder are present throughout the Gulf and East coast of the U.S., but the relative importance of the different paralichthids shifts regionally. In particular, there is a shift to Gulf flounder in the northeastern Gulf and summer flounder on the East coast. While comparisons with other studies indicated that regional trends occur across the range of southern flounder and associated flatfishes, caution must be exercised when interpreting these patterns because experimental design features were quite different among the studies examined (e.g., sampling effort, time and location of collections within the estuary, sampled habitats, gear type used).

Large-scale spatial variation in densities of newly settled southern flounder was found in GBE in 2005, with East Bay appearing to represent a hotspot for settlement. Densities in East Bay were significantly higher than the other two regions of the GBE ranging from 0.4 to 21.7 fish per $100 \mathrm{~m}^{2}$. Differences in settlement numbers of flatfishes at large scales (e.g. estuarine complex) have been reported and are often linked to spatial variation in environmental conditions, with species often more abundant in areas of the estuary where conditions are within the desired range (Burke et al. 1998). Several studies have determined that salinity is an important environmental scalar for flatfishes particularly during early life (Miller et al. 1991; Gibson 1994). More specifically, Burke 
et al. (1991) reported that southern flounder distribution in North Carolina estuaries was determined in part by salinity with highest catches at lower salinities. Therefore, it is possible that higher numbers of southern flounder observed in East Bay were partly a function of salinity since the region had significantly lower salinities (8-17 ppt) than the other bays. While salinity is one possible explanation for observed patterns, other abiotic factors (temperature, dissolved oxygen) varied across the bays sampled and may have influenced observed patterns of habitat use.

In addition to water quality parameters, physical processes (e.g., wind driven currents, tidal forcing) can determine the supply of larvae to a region, and have been shown to influence patterns of settlement as well as nursery habitat use (Bell and Westoby 1986; Jenkins et al. 1997; Brown et al. 2005). Jenkins and Black (1994) compared the temporal settlement patterns of King George whiting (Sillaginodes punciaia) to movements of passive particles in a bay system and determined that settlement was largely influenced by coastal hydrodynamic processes. Similarly, Brown et al. (2005) examined the link between physical processes and larval supply to estuarine nurseries in south Texas using a circulation model coupled with a fixed-depth particle transport model, and found that the proximity of the inlet to the nursery ground and the approach path to the inlet were critical factors that influenced larval supply. Although a comparable model does not exist for the GBE, precluding any predictions of transport based on approach path, East Bay sampling sites were closer to the tidal inlet (Rollover Pass) than sites in West Bay or Galveston Bay, possibly increasing the supply of recruits. Also, sites in East Bay are connected to coastal spawning areas by two tidal passes rather than one, which may increase the supply of larvae, particularly if southern flounder 
recruits from two different spawning areas converge on the same nursery habitats in East Bay.

Small-scale, habitat-specific variation in density of flatfishes has also been reported and often attributed to a variety of environmental factors (Burke et al. 1991; Miller et al. 1991; Gibson 1994; Guindon and Miller 1995; Burke et al. 1998). Several studies have shown flatfishes to differentiate habitats by bottom sediment or grain size. McConnaughey and Smith (2000) observed that for yellowfin sole (Limanda aspera) and Alaskan plaice (Pleuronectes quadrituberculatus), sediment texture was the most important factor affecting distribution, more so than temperature or depth. Also, juvenile stone flounder (Kareius bicoloratus) and summer flounder have been found to prefer coarser sediments over finer, muddier sediments (Burke et al. 1991; Malloy et al. 1996). In addition to sediment type and grain-size, studies in North Carolina reported a partitioning of habitat by salinity between southern and summer flounder, with southern flounder more abundant in lower-salinity environments (Burke et al 1991). In the present study, no habitat-specific differences in densities were detected, indicating that responses to conditions across nursery habitats were relatively equal. The apparent lack of a habitat effect is not surprising because environmental qualities (DO, temperature, salinity) and substrate condition were similar among habitat types within the same site. Also, the lack of a co-occurring paralichthid (e.g. Gulf flounder or summer flounder) in the study area may have allowed southern flounder to utilize several habitats rather than partitioning available resources to minimize overlap. Making deductions from salinity or sediment type alone is cautioned since these are often linked to one another and temperature. 
Peak recruitment of southern flounder juveniles in the GBE occurred in January and February, with the majority of recruits being derived from early-winter (late December to early January) spawning events (based on hatch-date distribution). Findings from the present study were accord with previous reports of early winter spawning of adult southern flounder (Ginsburg 1952; Richards 2006). The timing of peak recruitment of southern flounder in the GBE was slightly earlier than in North Carolina, which occurred in late February (Burke et al. 1991). Observed differences were relatively small and may have been due to natural variability (interannual effect) rather than a regional effect. Nonetheless, it is possible that warmer temperatures in the GBE may have been partly responsible for earlier spawning/settlement events. Collection numbers of southern flounder in the GBE decreased in March and only one southern flounder was captured in April. The decline in numbers was probably a function of emigration from settlement habitat(s) or increasingly successful avoidance of our sampling gear by larger flounder (Rogers et al. 1984; Burke 1995).

The RNA:DNA ratios of the fish in the present study ranged between 6.3 and 15.1, and laboratory-based condition levels (fed versus starved; G.J. Holt, unpublished data) indicated southern flounder in the GBE were in good nutritional condition. Observed ratios are well above a minimum ratio for fed larvae of winter flounder (3.2 to 3.5) and starved Japanese flounder (1.4 to 3.8), and within the ranges found for wildcaught summer flounder ( 2.75 to 7.5) (Buckley 1984; Malloy and Targett 1994; Gwak and Tanaka 2001), suggesting food was not a limiting factor in any of the bays or habitats sampled. Rooker and Holt (1997) reported RNA:DNA ratios of wild red drum from Texas estuaries and, similar to the present study, they found the nutritional condition of 
wild-caught individuals was well above the minimum or starved baseline estimate. This indicates that prey resources were likely adequate for newly settled southern flounder and food was not a limiting factor for new recruits during the 2005 sampling season.

RNA:DNA ratios of southern flounder in the GBE varied spatially, and ratios were significantly lower in West Bay than in either Galveston Bay or East Bay. Observed differences were possibly related to temperature differences among the bays. Specifically, water temperature in West Bay at the time of collection was approximately $2^{\circ} \mathrm{C}$ lower than in the other two bays. Moreover, RNA:DNA ratios were highest in the bay with the highest water temperature at time of collection. A positive relationship between water temperature and RNA:DNA ratio is not unexpected as protein synthesis increases with increasing temperature (Fry 1971). In fact, several studies have reported relationships between temperature and RNA:DNA ratio, including work on flatfishes and other marine teleosts (Buckley 1984; Ferron and Leggett 1994; Mathers et al. 1993; Malloy and Targett 1994; Calderone et al. 2003; Mercaldo-Allen et al. 2006). Even though the RNA:DNA ratio appears to vary as a function of temperature, work on larval and metamorphosing Japanese flounder showed no effect (Gwak and Tanaka 2001), suggesting this approach may not be a good proxy for nutritional condition or growth during transition periods. Still, flounder in aforementioned study were much smaller and at different life history stage than those in the present study.

All bays and habitats in the GBE supported equivalent growth, with a mean rate of $0.40 \mathrm{~mm} \mathrm{~d}^{-1}$ (range $0.21-0.76 \mathrm{~mm} \mathrm{~d}^{-1}$ ). Our growth estimates were comparable to those for other paralichthids, including summer flounder $0.11-0.27 \mathrm{~mm} \mathrm{~d}^{-1}$ (Necaise et al. 2005), Japanese flounder (Paralichthys olivaceus) $0.34-0.93 \mathrm{~mm} \mathrm{~d}^{-1}$ (Gwak et al. 2003), 
and fourspot flounder 0.40-0.60 $\mathrm{mm} \mathrm{d}^{-1}$ (Reichert and van der Veer 1991). Also, observed growth rates for southern flounder fell into the range reported for caged southern flounder in Pamlico Sound, NC: 0.07 to $0.79 \mathrm{~mm} \mathrm{~d}^{-1}$ (Guindon and Miller 1995). Still, field estimates are lower than the 1.2 to $1.4 \mathrm{~mm} \mathrm{~d}^{-1}$ rate obtained in laboratory settings (Peters 1971; Reichert and van der Veer 1991). Differences in growth between lab and field conditions were likely a function of water temperature, which was lower in the field $\left(10-24^{\circ} \mathrm{C}\right)$ than controlled conditions in the lab $\left(30^{\circ} \mathrm{C}\right)$ (Peters 1971). Moreover, another confounding factor in growth rate comparisons was the size of the fish being compared. Southern flounder in our study were smaller than southern flounder evaluated in other studies (Reichert and van der Veer 1991; Fitzhugh and Rice 1995; Guindon and Miller 1995).

Otolith increment widths are often used to estimate recent growth of fishes within the estuary and several studies have shown the approach to be useful for estimating the condition of flatfishes (Karakiri et al. 1989; Amara and Galois 2004). In the present study, otolith increment widths of southern flounder were used to evaluate their recent growth history. Recent growth was statistically similar among bays even though recent growth estimates were lower ( $22 \%$ on average) in the primary settlement site, East Bay. The East Bay trend was possibly linked to water temperature since it was lower in East Bay over the whole sampling period than in either Galveston Bay or West Bay. Other studies have reported similar relationships between temperature and otolith growth (e.g., Hoff and Fuiman 1993; Barber and Jenkins 2001; Fey 2005). Recent growth was also similar among habitat types sampled. Estimates of recent growth among habitat types have also been reported for post-settlement red drum in other Texas estuaries (Rooker 
and Holt 1997; Stunz et al. 2002). Similar to the present study, recent growth rates of red drum did not vary among habitat types, suggesting the growth potential was relatively equal among habitat types. It should be noted that high variability and small sample sizes reduced the power of recent growth assessments on southern flounder and thus could have been responsible for non-significant results. Moreover, recent work by Johnson et al. (2002) indicated that a lag time of 20 to 30 days occurred between start of a stressor (food restriction) and significant changes in otolith growth. Since the majority of southern flounder used for recent growth analysis were new settlers in the GBE $(<15$ day post-settlement), it is possible that habitat-specific differences in growth could not be detected due to the reported lag effect. However, thinking is divided on possible lag effects as Folkvord et al. (2000) found that the positive effects of increased prey densities showed up in otoliths within a few days in herring larvae. 


\section{SUMMARY AND CONCLUSIONS}

Findings from the current study suggest density and condition of newly settled southern flounder vary at the bay scale, suggesting that parts of GBE do not function equally as nurseries. In contrast, at a smaller scale (i.e. habitat-specific), differences in density, condition, and growth were negligible among habitats in close proximity. Physical processes likely play an important role in determining the settlement densities of southern flounder at the GBE scale and evidence from our preliminary sampling in 2004 support this hypothesis (see Appendix 2). Namely, densities were markedly lower and settlement densities were similar among the three bays. Low densities of southern flounder present in the GBE in both years may also indicate that they are recruitment limited. Miller et al. (1991) reported that the main factor(s) controlling year class strength of flatfishes occurs during the pre-settlement period, which lends some support to this idea. Even though settlement numbers in certain areas of the GBE were higher than others (e.g. East Bay), the actual nursery value of these bays will ultimately be related to the contributions made by each bay to adult populations (Beck et al. 2001). While East Bay may indeed be a hotspot for settlement, lower density areas in the GBE may contribute a large portion to the adult population. Across all habitat types examined, we also observed that growth was relatively similar and thus a variety of habitats maintained conditions favorable for growth and survival of newly settled southern flounder. Consequently, it appears that either nursery value of the habitat was similar or newly settled southern flounder are a highly adaptive fish that can utilize a variety of habitat types in the GBE as nursery grounds. 


\section{LITERATURE CITED}

Able, K. W. and M. P. Fahay. 1998. The first year of the life of estuarine fishes in the Middle Atlantic Bight. Rutgers University Press, New Brunswick, New Jersey.

Allen, R. L. and D. M. Baltz. 1997. Distribution and microhabitat use by flatfishes in a Louisiana estuary. Environmental Biology of Fishes 50: 85-103.

Amara, R. and R. Galois. 2004. Nutritional condition of metamorphosing sole: spatial and temporal analyses. Journal of Fish Biology 64: 72-88.

Barber, M. C. and G. P. Jenkins. 2001. Differential effects of food and temperature lead to decoupling of short-term otolith and somatic growth rates in juvenile King George whiting. Journal of Fish Biology 58(5): 1320-1330.

Beck, M. W., K. L. Heck Jr., K. W. Able, D. L. Childers, D. B. Eggleston, B. M. Gillanders, B. Halpern, C. G. Hays, K. Hoshino, T. J. Minello, R. J. Orth, P. F. Sheridan, and W. P. Weinstein. 2001. The identification, conservation, and magement of estuarine and marine nurseries for fish and invertebrates. BioScience 51(8):663-641.

Bell, J. D. and M. Westoby. 1986. Variations in seagrass height and density over a wide spatial scale: effects on fish and decapods. Journal of Experimental Marine Biology and Ecology 104: 275-295.

Brown, C. A., G. A. Jackson, S. A. Holt and G. J. Holt. 2005. Spatial and temporal patterns in modeled particle transport to estuarine habitat with comparisons to larval fish settlement patterns. Estuarine, Costal and Shelf Science 64: 33-46.

Buckley, L. J. 1984. RNA-DNA ratio: an index of larval fish growth in the sea. Marine Biology 80:291-298. 
Buckley, L. J., S. I. Turner, T. A. Halavik, A. S. Smigielski, S. M. Drew and G. C. Laurence. 1984. Effects of temperature and food availability on growth, survival and RNA-DNA ratio of larval and sand lance (Ammodytes americanus). Marine Ecological Progress Series 15:91-97.

Bulow, F. J. 1987. RNA-DNA ratios as indicators of growth in fish: a review. In Summerfelt, R.C. and GE Hall (eds.), The Age and Growth of Fish. The Iowa State University Press, Ames, Iowa.

Burke, J. S. 1995. Role of feeding and prey distribution of summer and southern flounder in selection of estuarine nursery habitats. Journal of Fish Biology 47:355-366.

Burke, J. S, J. M. Miller, and D. E. Hoss. 1991. Immigration and settlement pattern of Paralichthys dentatus and $P$. lethostigma in an estuarine nursery ground, North Carolina, USA. Netherlands Journal of Sea Research 27(3-4):393-405.

Burke, J. S., M. Ueno, Y. Tanaka, H. Walsh, T. Maeda, I. Kinoshita, T. Seikai, D. E. Hoss and M. Tanaka. 1998. The influence of environmental factors on early life history patterns of flounders. Journal of Sea Research 40: 19-32.

Caldarone, E. M., J. M. St. Onge-Burns, L. J. Buckley. 2003. Ralationship of RNA/DNA ratio and temperature to growth in larvae of Atlantic cod Gadus morhua. Marine Ecology Progress Series 262: 229-240.

Campana, S. E. and J. D. Neilson. 1985. Microstructure of fish otoliths. Canadian Journal of Fisheries Aquatic Science 42:1014-1032. 
Cowan, J. H. and R. F. Shaw. 2002. Recruitment. In L. A. Fuiman and R. G. Werner (eds.), Fishery Science: The Unique Contribution of Early Life Stages. Blackwell Science, Oxford, UK.

Cushing, D. H. 1996. Towards a Science of Recruitment in Fish Populations. Ecology Institute, Oldendorf, Germany.

Cushing, D. H. and J. W. Horwood. 1994. The growth and death of fish larvae. Journal of Plankton Research 16(3):291-300.

Ferron, A. and W. C. Leggett. 1994. An appraisal of condition measures for marine fish larvae. Advances in Marine Biology 30:217-303.

Fey, D. P. 2005. Is the marginal otolith increment width a reliable recent growth index for larval juvenile herring? Journal of Fish Biology 66: 1692-1703.

Fischer, A. J. and B. A. Thompson. 2004. The age and growth of southern flounder, Paralichthys lethostigma, from Louisiana estuarine and offshore waters. Bulletin of Marine Science 75(1):63-77.

Fitzhugh, G. R., L. B. Crowder, and J. P. Monaghan Jr. 1996. Mechanisms contributing to variable growth in juvenile southern flounder (Paralichthys lethostigma). Canadian Journal of Fisheries Aquatic Science 53:1964-1973.

Fitzhugh, G. R. and J. A. Rice. 1995. Error in back-calculation of lengths of juvenile southern flounder, Paralichthys lethostigma, and implications for analysis of sizeselection. In D. H. Secor, J. M. Dean, and S. F. Campana (eds.), Recent Developments in Fish Otolith Research. University of South Carolina Press, Columbia, South Carolina. 
Folkvord, A., G. Blom, A. Johannessen and E. Moksness. 2000. Growth-dependent age estimation in herring (Clupea harengus L.) larvae. Fisheries Research 46(1-3): 91-103.

Gibson, R. N. 1994. Impact of habitat quality and quantity on the recruitment of juvenile flatfishes. Netherlands Journal of Sea Research 32(2):191-206.

Ginsburg, I. 1952. Flounders of the genus Paralichthys and related genera in American waters. Fishery Bulletin 71(52): 267-351.

Guindon, K. Y. and J. M. Miller. 1995. Growth potential of juvenile southern flounder, Paralichthys lethostigma, in low salinity nursery areas of Pamlico Sound, North Carolina, USA. Netherlands Journal of Sea Research 34(1-3):89-100.

GSMFC- Gulf States Marine Fisheries Commission. 2000. The Flounder Fishery of the Gulf of Mexico, United States: a Regional Management Plan. S. J. VanderKooy, (ed.). Publication 83. Gulf States Marine Fisheries Commission, Ocean Springs, Mississippi.

Gwak, W. S. and M. Tanaka. 2001. Developmental change in RNA:DNA ratios of fed and starved laboratory-reared Japanese flounder larvae and juveniles, and its application to assessment of nutritional condition for wild fish. Journal of Fish Biology 59: 902-915.

Gwak, W. S. and M. Tankaka. 2002. Changes in RNA, DNA and protein contents of laboratory-reared Japanese flounder Paralichthys olivaceus during metamorphosis and settlement. Fisheries Science 68:27-33. 
Gwak, W. S., T. Tsusaki, and M. Tanaka. 2003. Nutritional condition, as evaluated by RNA/DNA ratios, of hatchery-reared Japanese flounder from hatch to release. Aquaculture 219: 503-514.

Hjort, J. 1914. Fluctuations in the great fisheries of northern Europe viewed in the light of biological research. Rapports et Proces-verbaux der Reunions, Conseil International pour l'Exploration de la Mer, 20:1-228.

Hoese, H. D. and R. H. Moore. 1998. Fishes of the Gulf of Mexico, Second Edition. Texas A\&M University Press, College Station, Texas.

Hoff, G. R. and L. A. Fuiman. 1993. Morphometry and composition of red drum otoliths: changes associated with temperature, somatic growth rate, and age. Comparative Biochemistry and Physiology 106A: 209-219.

Houde, E. D. 1987. Fish early life dynamics and recruitment variability. American Fisheries Society Symposium 2:17-29.

Iles, T. C. and R. J. H. Beverton. 2000. The concentration hypothesis: the statistical evidence. ICES Journal of Marine Science 57:216-227.

Imsland, A. K., A. Foss, S. W. Bonga, E. van Ham and S. O. Stefansson. 2002. Comparison of growth and RNA:DNA ratios in three populations of juvenile turbot reared at two salinities. Journal of Fish Biology 60(2): 288-300.

Jenkins, G. P. and K. P. Black. 1994. Temporal variability in settlement of coastal fish (Sillaginodes punctata) determined by low-frequency hydrodynamics. Limnology and Oceanography 39:1744-1754.

Jenkins, G. P., K. P. Black, M. J. Wheatley and D. N. Hatton. 1997. Temporal and spatial variability in recruitment of a temperate, seagrass-associated fish is largely 
determined by physical processes in the pre- and post-settlement phases. Marine Ecology Progress Series 148: 23-35.

Johnson, M. W., J. R. Rooker, D. M. Gatlin III and G. J. Holt. 2002. Effects of variable ration levels on direct and indirect measures of growth in juvenile red drum (Sciaenops ocellatus). Journal of Experimental Marine Biology and Ecology 274: $141-157$.

Jones, P. G. 1990. The importance of recruitment to the dynamics of a coral reef fish population. Ecology 71(5):1691-1698.

Karakiri, M., R. Berghahn and H. van Westernhagen. 1989. Growth differences in 0group plaice Pleuronectes platessa as revealed by otolith microstructure analysis. Marine Ecology Progress Series 55: 15-22.

Leggett, W. C. and E. DeBlois. 1994. Recruitment in marine fishes: is it regulated by starvation and predation in the egg and larval stages? Netherlands Journal of Sea Research 32(2):119-134.

Malloy, K. D. and T. E. Targett. 1994. The use of RNA:DNA ratios to predict growth limitation of juvenile summer flounder (Paralichthys dentatus) from Delaware and North Carolina estuaries. Marine Biology 118: 367-375.

Malloy, K. D., Y. Yamashita, H. Yamada, and T. E. Targett. 1996. Spatial and temporal patterns of juvenile stone flounder Kareius bicoloratus growth rates during and after settlement. Marine Ecology Progress Series 131:49-59.

Mathers, E. M., D. F. Houlihan, I. D. McCarthy and L. J. Burren. 1993. Rates of growth and protein synthesis correlated with nucleic acid content in fry of rainbow trout, 
Oncorhynchus mykiss: effects of age and temperature. Journal of Fish Biology 43: 245-263.

McConnaughey, R. A. and K. R. Smith. 2000. Associations between flatfish abundance and surficial sediments in the eastern Bering Sea. Canadian Journal of Fisheries and Aquatic Science 57:2410-2419.

McCurdy, W. J. cont. J. Panfili, F. J. Meunier, A. J. Geffen and H. de Pontual. 2002. Preparation and observation techniques: (C) Preparation of calcified structures. In Panfili, J., H. de Pontual, H. Troadec and P. J. Wright (eds.), Manual of Fish Sclerochronology. Ifremer-IRD coedition, Brest, France.

McEachran, J. D. and J. D. Fechhelm. 2006. Fishes of the Gulf of Mexico. University of Texas Press, Austin, Texas.

Mercaldo-Allen, R., C. Kuropat and E. M. Caldarone. 2006. A model to estimate growth in young-of-the-year tautog, Tautoga onitis, based on RNA/DNA ratio and seawater temperature. Journal of Experimental Marine Biology and Ecology 329: 187-195.

Miller, J. M., J. S. Burke and G. R. Fitzhugh. 1991. Early life history patterns of Atlantic North American flatfish: likely (and unlikely) factors controlling recruitment. Netherlands Journal of Sea Research 27(3-4):261-275.

Nall, L. E. 1979. Age and growth of southern flounder, Paralichthys lethostigma, in the northern Gulf of Mexico with notes on Paralichthys albigutta. M.S. Thesis, Florida State University College of Arts and Sciences, Tallahassee, Florida. 
Necaise, A. M. D., S. W. Ross and J. M. Miller. 2005. Estuarine habitat evaluation measured by growth of juvenile summer flounder Paralichthys dentatus in a North Carolina estuary. Marine Ecology Progress Series 285: 157-168.

Pannella, G. 1971. Fish otoliths- daily layers and periodical patterns. Science 172: $1124-1127$.

Peters, D. S. 1971. Growth and energy utilization of juvenile flounder, Paralichthys dentatus and Paralichthys lethostigma, as affected by temperature, salinity and food availability. Ph.D. Dissertation North Carolina State University, Raleigh, North Carolina.

Reichert, M. J. M. and H. W. van der Veer. 1991. Settlement, abundance, growth and mortality of juvenile flatfish in a subtropical tidal estuary (Georgia, USA). Netherlands Journal of Sea Research 27(3/4): 375-391.

Richards, W. J. (ed.). 2006. Early Stages of Atlantic Fishes: An Identification Guide for the Western Central North Atlantic, Volume II. Taylor \& Francis Group, Boca Raton, Florida.

Rogers, S. G., T. E. Targett and S. B. Van Sant. 1984. Fish-nursery use in Georgia saltmarsh estuaries: the influence of springtime freshwater conditions. Transactions of the American Fisheries Society 113: 595-606.

Rooker, J. R. and G. J. Holt. 1996. Application of RNA:DNA ratios to evaluate the condition and growth of larval and juvenile red drum (Sciaenops ocellatus). Marine and Freshwater Research 47:283-290. 
Rooker, J. R. and S. A. Holt. 1997. Utilization of subtropical seagrass meadows by newly settled red drum Sciaenops ocellatus: patterns of distribution and growth. Marine Ecology Progress Series 158: 139-149.

Sinclair, M. 1988. Marine Populations: An Essay on Population Regulation and Speciation. University of Washington Press, Seattle.

Stoner, A. W., J. P. Manderson and J. P. Pessutti. 2001. Spatially explicit analysis of estuarine habitat for juvenile winter flounder: combining generalized additive models and geographic information systems. Marine Ecological Progress Series 213:253-271.

Stunz, G. W., T. H. Linton and R. L. Colura. 2000. Age and growth of southern flounder in Texas waters, with emphasis on Matagorda Bay. Transactions of the American Fisheries Society 129:119-125.

Stunz, G. W., T. J. Minello and P. S. Levin. 2002. Growth of newly settled red drum Sciaenops ocellatus in different estuarine habitat types. Marine Ecology Progress Series 238: 227-236.

Topp, R. W. and F. H. Hoff. 1972. Memoirs of the Hourglass Cruises. Volume 4, Part 2. Marine Research Laboratory. Florida Department of Natural Resources, St. Petersburg, Florida.

Weinstein, M. P. 1979. Shallow marsh habitats as primary nurseries for fishes and shellfish, Cape Fear River, North Carolina. Fishery Bulletin 77(2): 339-357.

Westerman, M. E. and G. J. Holt. 1988. The RNA-DNA ratio: measurement of nucleic acids in larval Sciaenops ocellatus. Contributions in Marine Science 50:117-124. 


\section{APPENDIX}

Table A-1. Total numbers of collected ichthyofuan from each region of the Galveston

Bay Estuary during preliminary sampling round 1 (end of February-beginning of March)

in 2004 .

\begin{tabular}{|c|c|c|c|}
\hline \multicolumn{4}{|c|}{ Total Ichthyofuna Collected } \\
\hline Species & East Bay & Galveston Bay & West Bay \\
\hline Atlantic croaker & 540 & 150 & 115 \\
\hline Bay whiff & 34 & 25 & 49 \\
\hline Bighead sea robin & 3 & & 1 \\
\hline Clown goby & 2 & 2 & 8 \\
\hline Code goby & & & 6 \\
\hline Darter goby & 112 & 27 & 126 \\
\hline Eel species & & 1 & \\
\hline Fringed flounder & & 5 & \\
\hline Gulf flounder & & & 1 \\
\hline Gulf killifish & 2 & 3 & \\
\hline Gulf pipefish & & & 6 \\
\hline Highfin goby & 1 & & \\
\hline Hogchoker & & 1 & \\
\hline Inland silverside & & & 1 \\
\hline Kingfish & & 1 & \\
\hline Leptocephalus larvae & 4 & 4 & \\
\hline Naked goby & 22 & 8 & 1 \\
\hline Non-Paralicthid flatfish & & 1 & \\
\hline Pinfish & 98 & 87 & 219 \\
\hline Rainwater killifish & & & 2 \\
\hline Red drum & 1 & 4 & \\
\hline Sailfin molly & 1 & & \\
\hline Skillet fish & & 2 & \\
\hline Southern flounder & 12 & 3 & 15 \\
\hline Southern kingfish & & 1 & \\
\hline Spot & 3 & 1 & 1 \\
\hline Texas pipefish & & & 8 \\
\hline Texas silverside & & 1 & \\
\hline Twoscale goby & & 1 & \\
\hline Anchovy & 1203 & 1698 & 66 \\
\hline Blackcheek tonguefish & 4 & 4 & 2 \\
\hline Mullet spp. & 8 & 31 & 1 \\
\hline Sheepshead minnow & & & 11 \\
\hline
\end{tabular}


Table A-2. Total numbers of collected flatfish from three regions of the Galveston Bay Estuary during three preliminary sampling rounds in 2004. Round 1=end of Februarybeginning of March. Round 2=April. Round 3=June.

\begin{tabular}{|c|c|c|c|}
\hline \multicolumn{4}{|l|}{ East Bay } \\
\hline & \multicolumn{3}{|l|}{ Sampling Round } \\
\hline Species & 1 & 2 & 3 \\
\hline Bay whiff & 34 & 197 & 24 \\
\hline Fringed flounder & & 1 & \\
\hline Gulf flounder & & & \\
\hline Hogchoker & & & \\
\hline Non-Paralicthid flatfish & & & \\
\hline Southern flounder & 12 & 1 & \\
\hline Blackcheek tonguefish & 4 & 6 & 2 \\
\hline \multicolumn{4}{|l|}{ Galveston Bay } \\
\hline & \multicolumn{3}{|l|}{ Sampling Round } \\
\hline Species & 1 & 2 & 3 \\
\hline Bay whiff & 25 & 102 & 1 \\
\hline Fringed flounder & 5 & 1 & \\
\hline Gulf flounder & & 1 & \\
\hline Hogchoker & 1 & & \\
\hline Non-Paralicthid flatfish & 1 & & \\
\hline Southern flounder & 3 & & \\
\hline Blackcheek tonguefish & 4 & 1 & \\
\hline \multicolumn{4}{|l|}{ West Bay } \\
\hline & \multicolumn{3}{|l|}{ Sampling Round } \\
\hline Species & 1 & 2 & 3 \\
\hline Bay whiff & 49 & 197 & 12 \\
\hline Fringed flounder & & & \\
\hline Gulf flounder & 1 & 1 & \\
\hline Hogchoker & & & \\
\hline Non-Paralicthid flatfish & & & \\
\hline Southern flounder & 15 & 2 & \\
\hline Blackcheek tonguefish & 2 & 1 & \\
\hline
\end{tabular}


Table A-3. Complete records of RNA:DNA ratios from sub-sampled newly settled southern flounder collected in the Galveston Bay Estuary in 2005.

\begin{tabular}{|c|c|c|c|}
\hline SL (mm) & RNA:DNA ratio & RNA per protein & DNA per protein \\
\hline 23.3 & 13.58 & 0.1858 & 0.0263 \\
\hline 22.2 & 10.74 & 0.0321 & 0.0029 \\
\hline 9.7 & 6.85 & 0.0279 & 0.0038 \\
\hline 19.8 & 11.65 & 0.0396 & 0.0031 \\
\hline 22 & 8.06 & 0.0250 & 0.0030 \\
\hline 23.2 & 10.08 & 0.0661 & 0.0070 \\
\hline 19.1 & 9.57 & 0.0436 & 0.0044 \\
\hline 12.1 & 7.79 & 0.0619 & 0.0074 \\
\hline 12 & 6.34 & 0.0307 & 0.0046 \\
\hline 10.4 & 9.14 & 0.0505 & 0.0049 \\
\hline 10.6 & 10.39 & 0.0603 & 0.0061 \\
\hline 17 & 11.65 & 0.0272 & 0.0023 \\
\hline 10.8 & 6.36 & 0.0340 & 0.0053 \\
\hline 20.1 & 8.44 & 0.0236 & 0.0026 \\
\hline 15.8 & 10.51 & 0.0246 & 0.0023 \\
\hline 21.2 & 11.44 & 0.0525 & 0.0040 \\
\hline 10 & 9.49 & 0.0150 & 0.0015 \\
\hline 17.5 & 9.60 & 0.0199 & 0.0019 \\
\hline 11.1 & 8.35 & 0.0516 & 0.0055 \\
\hline 22.8 & 12.27 & 0.0548 & 0.0041 \\
\hline 25.4 & 15.19 & 0.0495 & 0.0030 \\
\hline 10.5 & 8.10 & 0.0352 & 0.0039 \\
\hline 21.7 & 10.57 & 0.0361 & 0.0035 \\
\hline 11.8 & 6.99 & 0.1551 & 0.0225 \\
\hline 19.1 & 9.81 & 0.0389 & 0.0036 \\
\hline 14.6 & 10.21 & 0.0475 & 0.0048 \\
\hline 17.9 & 8.24 & 0.0517 & 0.0064 \\
\hline 22 & 7.07 & 0.0386 & 0.0062 \\
\hline 11.7 & 9.18 & 0.0436 & 0.0047 \\
\hline 19.3 & 8.03 & 0.0332 & 0.0040 \\
\hline 17.1 & 9.87 & 0.0325 & 0.0033 \\
\hline 15.6 & 9.06 & 0.0332 & 0.0036 \\
\hline 14.9 & 8.82 & 0.0369 & 0.0040 \\
\hline 11.9 & 8.46 & 0.0680 & 0.0081 \\
\hline 9.7 & 8.76 & 0.0517 & 0.0057 \\
\hline 10.7 & 9.70 & 0.0562 & 0.0058 \\
\hline 14.2 & 8.78 & 0.0292 & 0.0035 \\
\hline 16 & 8.06 & 0.0253 & 0.0030 \\
\hline 12.6 & 8.95 & 0.0536 & 0.0064 \\
\hline 18.7 & 9.15 & 0.0613 & 0.0067 \\
\hline 15.3 & 9.12 & 0.0579 & 0.0060 \\
\hline 17.4 & 9.88 & 0.0516 & 0.0052 \\
\hline 17.6 & 9.95 & 0.0536 & 0.0056 \\
\hline 20.8 & 9.92 & 0.0359 & 0.0033 \\
\hline 19.3 & 8.97 & 0.0491 & 0.0049 \\
\hline 19.9 & 9.79 & 0.0452 & 0.0041 \\
\hline 19.1 & 8.25 & 0.0303 & 0.0035 \\
\hline 16 & 10.69 & 0.0303 & 0.0027 \\
\hline 18.9 & 10.68 & 0.0403 & 0.0037 \\
\hline
\end{tabular}




\section{VITA}

Lindsay Ann Glass received her Bachelor of Science degree in Marine Biology from Texas A\&M University at Galveston in May 2003. She entered the Wildlife and Fisheries Sciences program at Texas A\&M University in September 2004 and received her Master of Science degree in May of 2006.

Ms. Glass can be reached at Fisheries Ecology Lab, 5007 Ave U \#102, Galveston, TX 77551. Her e-mail address is glass1@tamug.edu. 